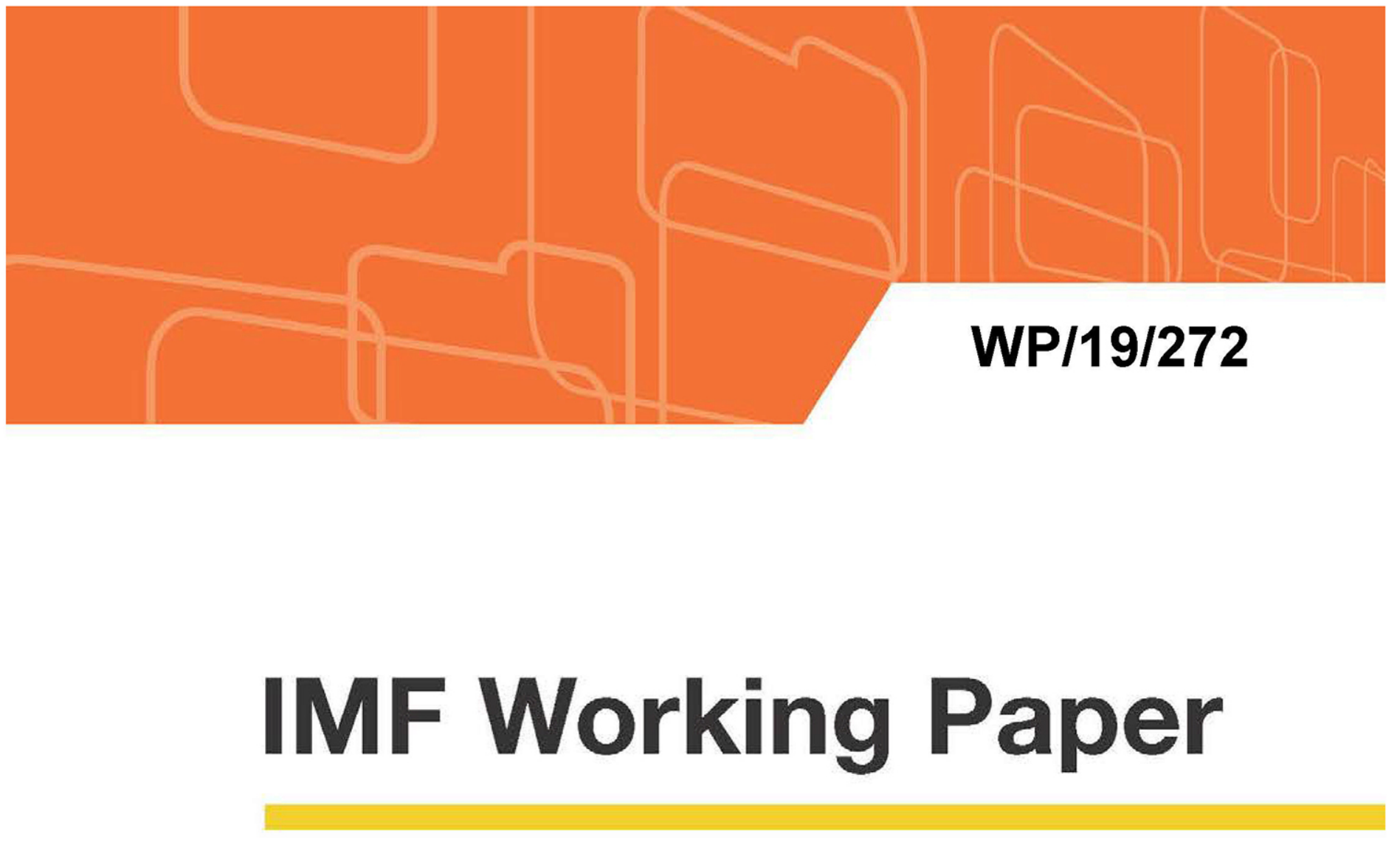

\title{
The Dynamics of Non-Performing Loans During Banking Crises:
}

\section{A New Database}

\author{
by Anil Ari, Sophia Chen, Lev Ratnovski
}

IMF Working Papers describe research in progress by the author(s) and are published to elicit comments and to encourage debate. The views expressed in IMF Working Papers are those of the author(s) and do not necessarily represent the views of the IMF, its Executive Board, or IMF management. 


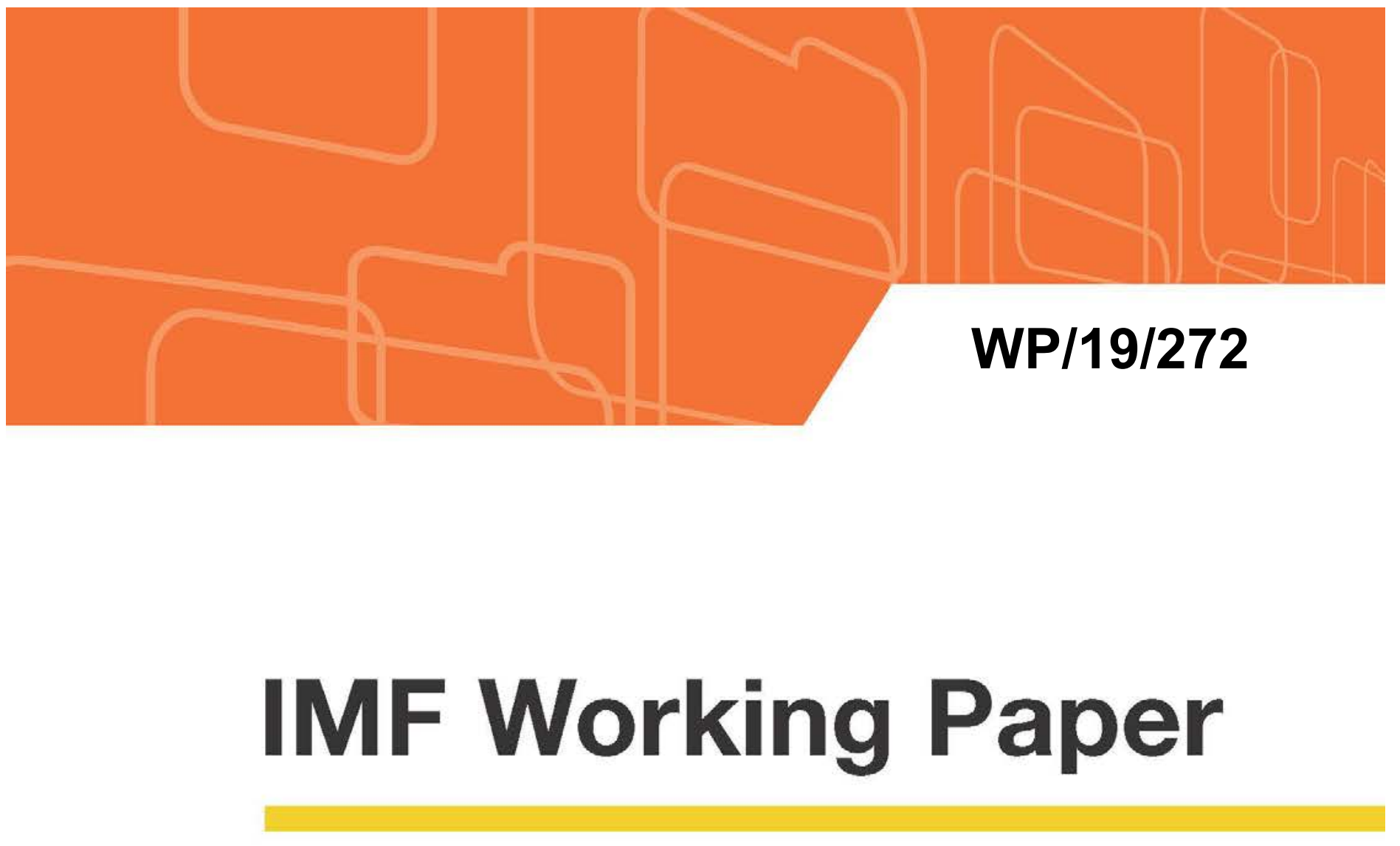

\section{The Dynamics of Non-Performing Loans During Banking Crises:}

A New Database

by Anil Ari, Sophia Chen, Lev Ratnovski

IMF Working Papers describe research in progress by the author(s) and are published to elicit comments and to encourage debate. The views expressed in IMF Working Papers are those of the author(s) and do not necessarily represent the views of the IMF, its Executive Board, or IMF management.

$$
\text { I N T ER N A T I O N A L M O NETAR Y FU N D }
$$




\title{
IMF Working Paper
}

Research Department

\section{The Dynamics of Non-Performing Loans During Banking Crises: A New Database Prepared by Anil Ari, Sophia Chen, and Lev Ratnovski ${ }^{1}$}

Authorized for distribution by Maria Soledad Martinez Peria

December 2019

\section{IMF Working Papers describe research in progress by the author(s) and are published to elicit comments and to encourage debate. The views expressed in IMF Working Papers are those of the author(s) and do not necessarily represent the views of the IMF, its Executive Board, or IMF management.}

\begin{abstract}
This paper presents a new dataset on the dynamics of non-performing loans (NPLs) during 88 banking crises since 1990. The data show similarities across crises during NPL build-ups but less so during NPL resolutions. We find a close relationship between NPL problems - elevated and unresolved NPLs - and the severity of post-crisis recessions. A machine learning approach identifies a set of pre-crisis predictors of NPL problems related to weak macroeconomic, institutional, corporate, and banking sector conditions. Our findings suggest that reducing precrisis vulnerabilities and promptly addressing NPL problems during a crisis are important for post-crisis output recovery.

JEL Classification Numbers: E32, E44, G21, N10, N20.

Keywords: non-performing loans, debt, banking crises, recessions, crisis resolution.

Author's E-Mail Address: aari@imf.org, ychen2@,imf.org, lev.ratnovski@ecb.europa.eu

\footnotetext{
${ }^{1}$ We are grateful to Maria Soledad Martinez Peria for her encouragement and helpful suggestions. We thank Gabriel Chodorow-Reich, Stijn Claessens, Giovanni Dell'Ariccia, Deniz Igan, Luc Laeven, and seminar and conference participants at the IMF and Yale School of Management's "Fighting a Financial Crisis" Conference for helpful comments. Excellent research assistance was provided by Chenxu Fu, Do Lee, Hala Moussawi, and Alex Osberghaus.
} 


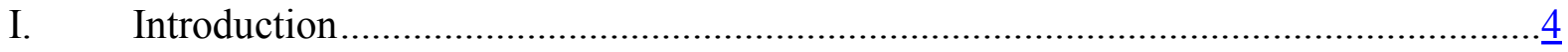

II. A Dataset on NPL Dynamics During Banking Crises ...........................................

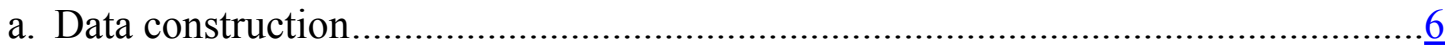

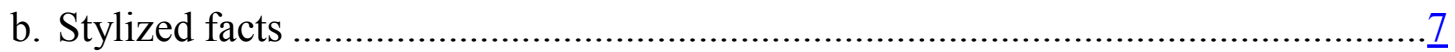

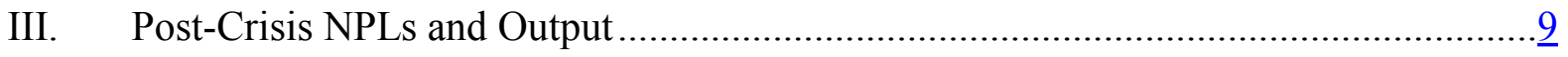

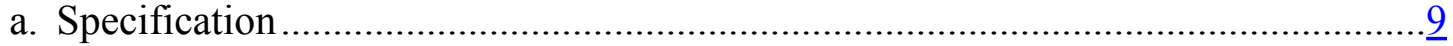

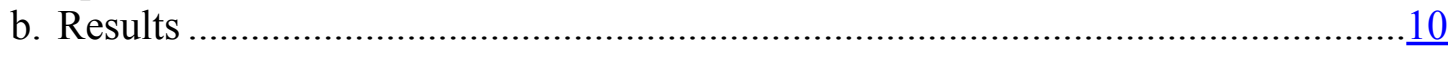

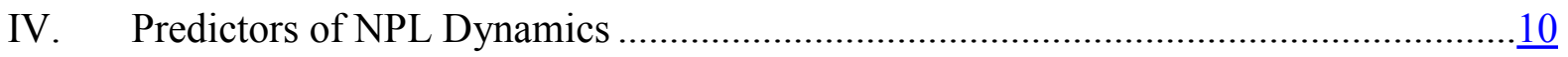

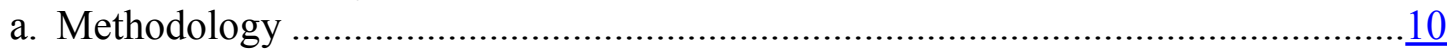

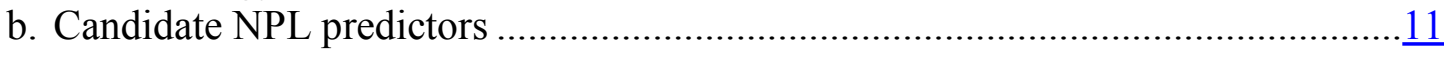

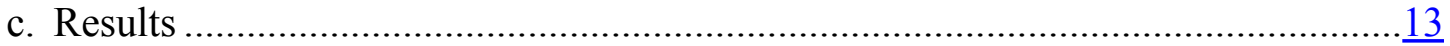

V. Application: NPLs in the European Crisis Countries ..........................................15

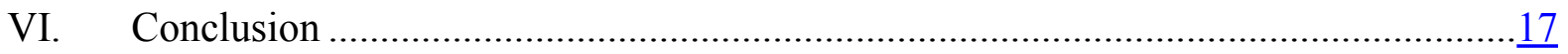

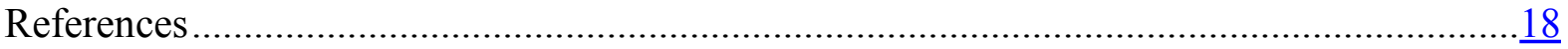

Tables

Table 1. Summary statistics …........................................................................... $\frac{33}{35}$

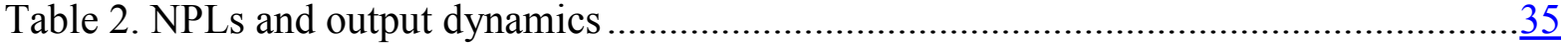

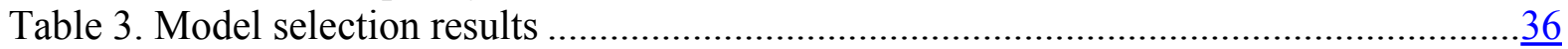

Table 4. Summary of predictors..............................................................................

Figures

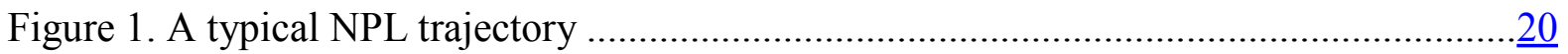

Figure 2. A new dataset on NPL dynamics............................................................

Figure 3. NPLs during banking crises around the world ...............................................

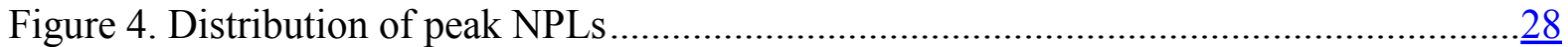

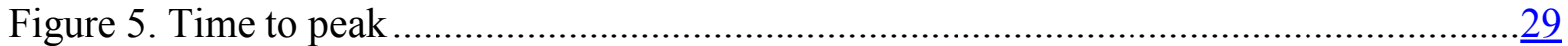

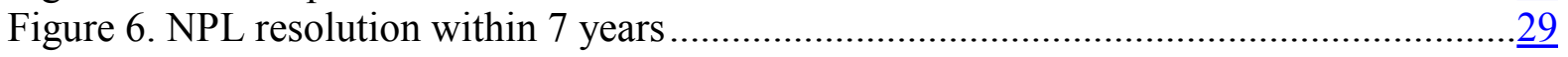

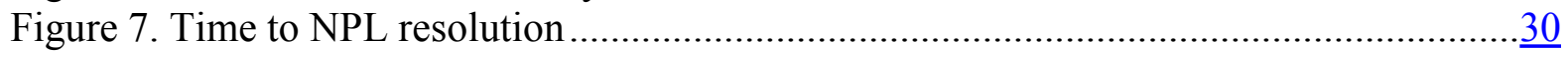

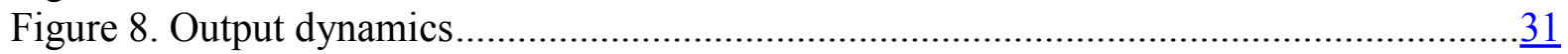

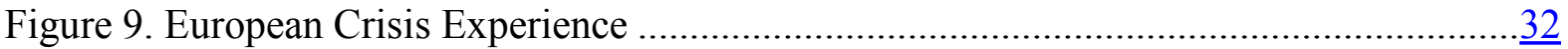




\section{INTRODUCTION}

Elevated levels of non-performing loans (NPLs) - loans that are in or close to default - are a common feature of many banking crises. The literature acknowledges that elevated NPLs impair bank balance sheets, depress credit growth, and delay output recovery (Aiyar et al., 2015; Kalemli-Ozcan, Laeven, and Moreno, 2015, IMF 2016). While it is important to address NPL problems expeditiously, the analysis of NPL dynamics during banking crises has so far been constrained by data limitations. We know little about the patterns of NPL build-up and the factors that affect NPL resolution. These are important policy issues, as some countries are still dealing with the NPLs created by the Global Financial Crisis (GFC) and the European sovereign debt crisis, while others have high leverage-related vulnerabilities (IMF, 2019).

This paper presents and analyzes a new dataset on NPL dynamics during banking crises. The dataset covers the yearly evolution of NPLs for 88 banking crises in 78 countries since 1990 . This includes all major regional and global crises during this period (e.g., the Nordic banking crisis, the Asian financial crisis, the GFC) and numerous standalone crises in transition and low-income economies. For each crisis, NPLs are reported over an 11-year long window that starts three years before the crisis and extends to seven years after the crisis. ${ }^{2}$

These data allow us to study NPL dynamics during banking crises in the most comprehensive way so far. We find that a large majority of crises (81 percent) exhibit elevated NPLs that exceed 7 percent of total loans. In nearly half the crises, NPLs more than double compared to the pre-crisis period. In their trajectory, NPLs typically follow an inverse U-shaped pattern (Figure 1). They start modest, rise rapidly around the start of the crisis, and peak some years afterwards, before finally stabilizing and declining. While there is much commonality across crises during the NPL build-up, the experiences during NPL resolution differ. The decline in NPLs is rapid in some cases and protracted in others. In 30 percent of the crises, NPLs remain above 7 percent of total loans 7 years after the start of the crisis. In a few cases, NPLs decline and peak again, forming an M-shaped pattern.

The new data also allow us to revisit a much-debated question on the determinants of postcrisis growth. Previous literature shows that economic growth falls after a banking crisis. ${ }^{3}$ Our data offers novel insights by highlighting a link between the dynamics of NPLs and post-crisis growth. We use the local projection (LP) method (Jordà, 2005) to track post-crisis NPL and output. We find a close relationship between elevated NPLs and the severity of post-crisis recessions. Output in crises with elevated and unresolved NPLs is persistently lower than in crises with low NPLs.

\footnotetext{
${ }^{2}$ A common time window facilitates comparisons across crises. The 11-year window of our analysis captures most NPL dynamics while minimizing confounding effects from unrelated post-crisis economic fluctuations. The companion dataset also includes NPLs beyond this window when available.

${ }^{3}$ For example, Cerra and Saxena (2008) estimate output losses amounting to 7.5 percent of GDP over a 10-year period after a crisis, Reinhart and Rogoff (2009a, 2009b) find that the peak-to-trough output decline is on average 9 percent after a crisis. Jordà, Schularick, and Taylor (2013) show a larger credit build-up is associated with a deeper recession.
} 
Given the close relationship between NPL dynamics and output growth post-crisis, it is important to understand the "risk factors" of adverse NPL dynamics. We use a machine learning approach to study which pre-crisis conditions matter for the likelihood of elevated NPLs, the duration and magnitude of NPL build-up, and the likelihood of timely NPL resolution. ${ }^{4}$ We find that countries with higher pre-crisis GDP per capita (which may proxy institutional strength) and lower corporate leverage are less likely to experience elevated NPLs during a crisis. For the crises with elevated NPLs, lower bank return on assets and shorter corporate debt maturities predict higher peak NPLs, while lower government debt, flexible exchange rates and higher growth predict faster NPL stabilization and resolution. Finally, NPL stabilization and resolution takes longer in crises higher pre-crisis credit growth. Overall, these results suggest that better ex-ante macroeconomic, institutional, corporate, and banking sector conditions and policies can help reduce NPL vulnerabilities during a crisis.

To put our results to use, we place the NPL experience in European crisis countries in the GFC in historic context. We ask to which extent NPL dynamics in those countries could have been anticipated, and whether NPL resolution has been on par with international experience. We show that slow NPL resolution in European crisis countries is predictable based on historic crisis experience and pre-crisis conditions, although the magnitude of peak NPLs was higher than the historic experience could have suggested, likely due to the subsequent sovereign debt crisis.

Our paper contributes to the literature on the causes and consequences of NPLs in several dimensions. First, we present a new comprehensive dataset on the multi-year NPL dynamics during banking crises. Our dataset complements existing data that only cover peak NPLs during banking crises (Laeven and Valencia, 2013, 2018), as well as data on general NPL dynamics over time (Balgova, Plekhanov, and Skrzypinska, 2017). ${ }^{5}$ We show that NPL dynamics during banking crises are distinct (NPLs are substantially higher and more volatile), implying possibly different causes and the need for different policies. Second, we contribute to the literature on post-crisis growth (Cerra and Saxena, 2008; Reinhart and Rogoff, 2009a, 2009b; Jordà, Schularick, and Taylor, 2013) with a new angle. We show that elevated and unresolved NPLs are an important factor for large and persistent decline in output after banking crises. Third, we add to the literature on the determinants of NPLs, which was previously based on country or region-specific data (e.g. Podpiera and Weill, 2008, and Ghosh, 2015, among others). Our contribution lies on the comprehensiveness of the data and the rigor of the methodology. Furthermore, our results have the practical merit of reducing the data

\footnotetext{
${ }^{4}$ Specifically, we use the "post rigorous least absolute shrinkage and selection operator" ("post-r-lasso"; Belloni et al., 2012; Belloni and Chernozhukov, 2013) model selection approach to determine the most informative combination of predictors for each NPL metric. This approach is particularly suitable to our analysis because of the large number of candidate NPL predictors relative to our sample size. See Section IV for further details.

${ }^{5}$ Apart from our focus on banking crises rather than normal times, our dataset differs from that of Balgova, Plekhanov, and Skrzypinska (2017). Much of the Balgova et al. (2017) data is inferred from Bankscope, which focuses on larger banks, making it unrepresentative of a country's overall banking system, and with coverage deteriorating back in time (Bhattacharya, 2003). In contrast, whenever available we hand-collected data from IMF Staff Reports and national sources that represent the countries' aggregate banking systems. Furthermore, we made substantial efforts to adjust for NPL definition differences across data sources to ensure consistency. See Section II for details.
} 
requirements for NPL risk monitoring, especially in a cross-country setting where detailed data is often scarce.

The findings of our paper have important policy implications. First, the close relationship between post-crisis output growth and NPLs points to the importance of macro-financial linkages in crisis recovery. Second, the identified risk factors of adverse NPL dynamics offer useful indicators for NPL risk monitoring. Our results also suggest that better ex-ante macroeconomic, financial, and institutional policies can alleviate the impact of banking crises. Finally, our analysis illustrates that reliable NPL data are vital for NPL monitoring and for the formulation of evidence-based NPL resolution polices.

The paper proceeds as follows. Section II describes the dataset and summarizes key stylized facts. Section III analyzes the relationship between post-crisis output growth and NPLs. Section IV studies the risk factors of NPL dynamics. Section V presents an application of our risk factors analysis to place the NPL experience of European countries after the GFC in a historic perspective. Section VI concludes with policy implications. The paper is complemented by an online Appendix and the full dataset.

\section{A Dataset On NPL Dynamics DURing Banking Crises}

\section{a. Data construction}

We construct a dataset on NPL dynamics during systemic banking crises from 1990 to 2017. From the universe of 106 such crises identified by Laeven and Valencia (2013, 2018), NPL data are available for 88 episodes in 78 countries. For each crisis, we report available NPL data over an 11-year long window that starts three years before the crisis and ends seven years after the crisis. ${ }^{6}$ This window is intended to capture the fact that NPL buildup tends to precede the crisis, while NPL resolution is often protracted.

We draw our NPL data from multiple sources and take steps to ensure their consistency. We start with NPL data from IMF's Financial Soundness Indicators (FSI). The FSI data cover 103 countries as of 2015 and offer comparable cross-country data thanks to detailed NPL classification guidelines. The shortcoming of the FSI is that the data start in 2001, with narrow country coverage early in the sample. ${ }^{7}$

When the FSI data are missing, we use hand-collected data from IMF Staff Reports. When both the FSI and Staff Report data are missing, we use hand-collect data from the official statistics of the national authorities or other national sources. We use Bankscope data only when none of the above data are available, due to two concerns with its reliability. First,

\footnotetext{
${ }^{6}$ Laeven and Valencia $(2013,2018)$ identify 108 banking crises. Because our goal is to analyze the dynamics of NPLs over the years, we combine crises in the same country with close timing into one episode (Brazil 1990 and 1994; and Democratic Republic of Congo 1991 and 1994). This gives us a sample of 106 episodes.

${ }^{7}$ Another commonly used cross-country NPL database is World Bank's Global Financial Development Database (GFDD). This is sourced from IMF FSI (with more historical data for some countries) and has only a few minor discrepancies with the FSI. Note that, in the IMF definition, the term "country" may cover entities that are not states as understood by international law and practice.
} 
Bankscope often only covers publicly-traded or large banks and thus omits the conditions of small banks. Second, the coverage is weak pre-2000s, with large fluctuation across years in some countries. Sample breaks that result from changing bank coverage can confound NPL dynamics observed in Bankscope.

We take multiple steps to ensure data consistency when we combine different data sources into a single time series. First, when extending the data from a more prioritized source using a less prioritized source, we require an overlap in the time coverage of the two sources. We multiplicatively rescale the less prioritized source to match the more prioritized source in the first overlapping year. ${ }^{8}$

Second, countries may have different regulatory definitions for NPLs: while the definition based on 90 days past-due principal and interest payments is the most common, some countries opt for stricter guidance to include loans less than 90 days past due. Also, the definitions of NPLs may be different across data sources. To avoid creating definitions-related data breaks, we only combine data sources when their definitions are consistent and the data discrepancy is minor (see Appendix A for further details on NPL definitions and data sources). While this conservative approach limits the sample coverage, it is crucial to ensure cross-country comparability of the data.

Figure 2 shows the resulting NPL series for each banking crisis identified in Laeven and Valencia (2018).

\section{b. Stylized facts}

NPLs are usually higher and more volatile during banking crises compared to normal times. The mean NPL to total loans ratio (hereafter NPL ratio) over the 11-year window around banking crises is 10 percent with a standard deviation of 10 percent. In comparison, the mean NPL ratio in normal times (i.e. outside the 11-year window) is 6 percent with a standard deviation of 6 percent. The difference in means is economically and statistically significant. ${ }^{9}$

A large majority of banking crises exhibit elevated NPLs. While NPLs are typically modest before a crisis, they rise substantially during the crisis and remain elevated for a long time (Figure 3). In over 80 percent of the crises, peak NPL ratio exceeds 7 percent (Figure 4 Panel A). All but one crisis with peak NPL ratio below 7 percent correspond to the GFC. ${ }^{10}$ In our baseline analyses, we use 7 percent as a threshold to define elevated NPLs. This threshold is

\footnotetext{
${ }^{8}$ Using scaling to combine two series with similar trend avoids creating artificial trends and data breaks in the combined series, which may occur with an interpolation or splicing method (e.g. Balgova, Plekhanov, and Skrzypinska, 2017).

${ }^{9}$ We collect data for normal time NPL ratios from IMF FSI and Bankscope. The F-test rejecting equal means is significant at the 1 percent level. We similarly obtain a difference of 4 percentage points between the two groups in regression analyses controlling for country and/or year fixed effects.

${ }^{10}$ The following crises had peak NPLs below 7 percent: Austria (2008), Belgium (2008), Denmark (2008), France (2008), Germany (2008), Haiti (1994), Luxembourg (2008), Netherlands (2008), Sweden (2008), Switzerland (2008), United Kingdom (2007), United States (2007).
}

(continued...) 
convenient because no crisis has a peak NPL ratio in a close neighborhood of 7 percent. We also investigate the robustness of our results to alternative thresholds.

In crises with elevated NPLs, peak NPL ratio reaches 22 percent on average and, in a few exceptional cases, exceeds 50 percent. Peak NPLs more than double the NPLs on the crisis date in almost half of the crises; and more than quadruple in 30 percent of the crises (Figure 4 Panel B). ${ }^{11}$

NPLs keep rising for 2.4 years on average following the start of the crisis. But in more than 20 percent of the crises, NPLs keep rising for four years or more (Figure 5). ${ }^{12}$ Notably, in over 30 percent of the crises, NPL ratios remain above 7 percent 7 years after the crisis - in other words, elevated NPLs are not resolved within our time window (Figure 6). For countries that manage to reduce NPL ratios to below 7 percent, there is much heterogeneity in achieving such a reduction, with an average of 5 years from the start of the crisis (Figure 7). ${ }^{13}$

Because banking crises are rarely single-country events, it is useful to compare NPL dynamics within and across different waves of crises. ${ }^{14}$ The Nordic banking crisis of the early 1990s was an example of effective NPL resolution in advanced economies. NPL ratios peaked at 9-10 percent in Finland, Norway, and Sweden soon after a housing downturn, and NPLs were resolved within 3 years in all three countries (see Figure 2).

Among Asian countries affected by the Asian financial crisis of the late 1990s, NPLs peaked rapidly (within 1 year) and were resolved slowly (over more than 7 years) in Malaysia and Thailand but peaked slowly (after 3 to 4 years) and were resolved rapidly (within 2 years of the peak) in Japan and Korea. During the same period, in countries outside Asia, NPLs tended to peak fast and be resolved within 7 years.

There is also much heterogeneity in the dynamics of NPLs during the GFC. In Europe, Latvia achieved the fastest NPL reduction: NPLs peaked 2 years after the crisis and were resolved a year after that. Outside Europe, Mongolia and Nigeria experienced the sharpest rise in NPLs. On average, NPL resolution after the GFC was slow compared to prior crises. As of end-2017, 9 out of 27 countries hit by the GFC were still saddled with elevated NPLs. ${ }^{15}$

A comparison between crises in advanced economies (AE) and emerging and developing economies (EM) shows EM tend to have higher peak NPLs than AE (Table 1, Panel C). In

\footnotetext{
${ }^{11}$ Pre-crisis NPLs are measured prior to the first year when NPL ratio increases (1) by more than 5 percentage points or (2) by more than 150 percent in a two-year period.

12 The crisis date is taken from Laeven and Valencia (2013, 2018), who define it as the first date when two conditions are met: (1) significant signs of financial distress in the banking system, as indicated by significant bank runs, losses in the banking system, and/or bank liquidations, and (2) significant banking policy intervention measures in response to significant losses in the banking system.

${ }^{13}$ The time to resolution is truncated at 8 years after the crisis date (or at 2017 for post-2010 crises).

${ }^{14}$ See Appendix Table $\mathrm{C} 1$ for the definition of crisis waves.

${ }^{15}$ These include Cyprus, Greece, Ireland, Italy, Portugal, Kazakhstan, Nigeria, Russia, and Ukraine.
}

(continued...) 
contrast, NPLs in AE take longer to peak and be resolved than in EM. These patterns also hold when we compare AE and EM within crisis waves. ${ }^{16}$

\section{Post-CRISIS NPLS AND OUTPUT}

We now proceed to a more formal analysis of the dataset. In this section, we study NPL dynamics during banking crises and their relationship with post-crisis output. We ask whether post-crisis output is lower in countries with elevated NPLs, and further lower in countries where elevated NPLs remain unresolved. We use the local projection (LP) method of Jordà (2005), which has been used in the literature to study the output path following financial distress (Jordà, Schularick and Taylor, 2013; Romer and Romer, 2017).

\section{a. Specification}

We start by assessing whether elevated NPLs affect the path of post-crisis output. We estimate the following impulse response system of equations:

$$
y_{i, t+h}=\alpha^{h}+\theta_{H}^{h} C_{i, t} \times H_{i}+\sum_{k=1}^{2} \Gamma_{k}^{h} Y_{i, t-k}+\tau_{c}^{h}+u_{i, t}^{h}
$$

where the subscripts $i$ and $t$ index crises and time respectively, and the superscript $h=1, \ldots, 7$ denotes the horizon (number of years after $t$ ) being considered. The dependent variable $y_{i, t+h}$ is real GDP (in logarithm, relative to $t$, multiplied by 100) for crisis $i$ at time $t+h$, which captures the cumulative changes in real GDP in the first $h$ years of the crisis. A negative $y_{i, t+h}$ reflects output loss and a positive $y_{i, t+h}$ reflects output gain since the crisis. $\alpha^{h}$ is the constant. $C_{i t}$ denotes banking crisis $i$ at time $t . H_{i}$ is a dummy variable that equals 1 if peak NPL ratio is above 7 percent in our baseline specification. Thus, $\theta_{H}^{h}$ captures the relative output loss (or gain) for crises with high NPLs compared to those with low NPLs. The vector of control variables $Y_{i, t-k}$ includes two lags of bilateral exchange rate against the U.S. dollar, of government-debt-to-GDP ratio, and of credit to the private sector (as a percentage of GDP), all measured in first differences. Our controls capture broad external, fiscal, and financial conditions that the literature has found to be related to post-crisis output dynamics. We also include two lags of NPL ratio and of real GDP growth to capture the pre-crisis relationship between NPLs and output. Finally, we include crisis wave fixed effects, $\tau_{c}^{h}$, to control for unobserved common factors in contemporaneous banking crises.

We then analyze whether the resolution of elevated NPLs improves growth outcomes. We estimate:

$$
y_{i, t+h}=\alpha^{h}+\lambda_{N R}^{h} C_{i, t} \times R_{i, t+h}+\sum_{k=1}^{2} \Gamma_{k}^{h} Y_{i, t-k}+\tau_{c}^{h}+u_{i, t}^{h}
$$

where $R_{i, t+h}$ is a dummy variable that equals 1 if the NPLs were resolved in year $t+h$. Thus, $\lambda_{N R}^{h}$ captures output differences between crises with resolved and unresolved NPLs in a given

\footnotetext{
${ }^{16}$ There are two exceptions. Peak NPLs during the Asian financial crisis were slightly lower in EM non-Asian countries than in AE non-Asian countries. Time to resolve during the Asian financial crisis was longer in EM non-Asian countries than in AE non-Asian countries.
} 
year. We consider NPLs to be resolved if they fall below 7 percent of total loans in our baseline specification.

\section{b. Results}

Output is on average lower in crises with elevated NPLs compared to those with low NPLs (Figure 8 Panel A and Table 2 Panel A). The difference in real GDP levels is 2.6 percent in the first year after a crisis and widens further in subsequent years, reaching 9.1 percent by the sixth year. These differences are statistically significant, as well as economically large.

Among crises with elevated NPLs, output is on average lower in countries with unresolved NPLs compared to those with resolved NPLs (Figure 8 Panel B and Table 2 Panel B). The difference in real GDP levels is 2 percent in the first year after a crisis, although this difference is not statistically significant. In subsequent years, the difference becomes economically larger and statistically significant, ranging from around 8 percent in the second and third year to over 16 percent in the fifth and sixth year.

All the results are robust when we use alternative 5 or 10 percent thresholds for elevated NPLs or NPL resolution (Appendix B). Our results are also robust to additional controls including exchange rate regime and CPI inflation, and to winsorizing the dependent variable.

Overall, our analysis suggests a new fact about post-crisis output dynamics: elevated and unresolved NPLs are associated with more severe recessions. Although these results do not imply causality, the close link between output losses and NPLs nevertheless points to the importance of elevated and unresolved NPLs in understanding the severity of post-crisis recessions.

\section{PREDICTORS OF NPL DYNAMICS}

In this section, we study what best predicts NPL dynamics in banking crises. We ask which pre-crisis factors best explain the likelihood of elevated NPLs, the length and magnitude of the NPL run-up, and the timeliness of NPL resolution.

\section{a. Methodology}

Economic intuition and the existing literature on NPLs (as will be discussed below) offer a vast set of candidate predictors for NPL dynamics. Given the limited number of historic banking crises, indiscriminately including all these predictors in the empirical analysis would lead to inflated standard errors and overfitting. We instead use a model selection approach to identify key NPL predictors. From a policy perspective, identifying a narrow set of predictors has the practical merit of reducing data requirements for risk monitoring.

We use the "post rigorous least absolute shrinkage and selection operator" ("post-r-lasso"; Belloni et al., 2012; Belloni and Chernozhukov, 2013) model selection approach to determine the most informative combination of NPL predictors. This approach is particularly useful when the number of candidate predictors is large relative to the sample size. Post-r-lasso is 
implemented in two steps. In the first step, the number of predictors is reduced by appending the least squares fitting criterion with a penalty parameter that shrinks the absolute sum of the coefficients of all predictors. The penalty parameter leads to lower variance and standard errors than those in the least-squares estimator at the expense of a downward bias in coefficients. In the second step, after obtaining the most informative set of predictors, their coefficients are reestimated without the penalty parameter to remove the bias. We use ordinary least squares (OLS) regression, unless the dependent variable is binary or truncated, in which case we use logistic and Tobit regressions respectively. ${ }^{17}$

We consider various metrics of NPL dynamics as introduced in Figure 1. We start with the likelihood of elevated NPLs, defined as NPLs exceeding 7 percent of total loans. For crises with elevated NPLs, we consider peak NPL ratio, the time it takes for NPLs to peak after the start of the crisis ("time to peak") and the time for NPLs to be resolved, that is, to decline to under 7 percent ("time to resolve"). We also examine the likelihood of timely NPL resolution ("NPL resolution dummy"), defined as whether NPLs decline to under 7 percent within 7 years from the start of the crisis.

We let the model selection algorithm choose from a rich set of candidate predictors capturing domestic and external macroeconomic, banking, and corporate conditions, and country institutional characteristics. The post-r-lasso method entails a trade-off between the sample size and the number of candidate predictors, since observations with missing predictor data are dropped from the sample. Because of this trade-off, we consider three alternative specifications. The first specification includes the largest sample of crises and the smallest set of predictors. This specification is then expanded to include additional predictors at the expense of smaller samples. Appendix Table C2 lists all variable definitions, and Table C3 reports the candidate predictors included in each specification.

We measure predictor variables before the crisis and all dependent variables on or after the crisis date. ${ }^{18}$ This staggered timing helps alleviate endogeneity concerns. Nevertheless, we do not ascribe a causal interpretation to our findings. The main goal of our exercise is to identify predictors useful for risk monitoring.

\section{b. Candidate NPL predictors}

Candidate predictors in the first specification include measures of domestic and external macroeconomic conditions, and institutional strength. We capture pre-crisis domestic macroeconomic conditions using GDP growth, domestic credit to the private sector, and unemployment and inflation rates. The relationship between these conditions and NPLs is theoretically ambiguous. On the one hand, weaker macroeconomic conditions may predict higher NPLs because of their adverse impact on borrowers' wealth and debt service capacity (Williamson, 1987; Bernanke and Gertler 1989; Bernanke and Gilchrist 1999; Kiyotaki and Moore 1997). On the other hand, high credit and GDP growth may reflect a credit boom with

\footnotetext{
${ }^{17}$ Our findings are robust to using probit instead of logistic regressions. We use Tobit regressions for "time to resolve" because this measure is truncated at 8 years after the crisis date (or 2017 for post-2010 crises).

${ }^{18}$ Predictor variables reflect averages or cumulative changes over the five years prior to the crisis.
} 
lower credit quality, leading to higher NPLs (Schularick and Taylor, 2012; Calomiris and Chen, 2018; Kirti, 2018). Although inflation may make it easier to service local currency debt by reducing its real value, it may also lead to higher nominal and real interest rates, which raise debt service costs. High inflation may also be associated with macroeconomic instability that exacerbates NPLs. Similar ambiguity is present for the impact of macroeconomic conditions on NPL resolution. Favorable pre-crisis macroeconomic conditions may aid NPL resolution if they leave more resources for borrowers and lenders to resolve the debts. However, strong growth fueled by a credit boom may imply lower credit quality, challenging NPL resolution.

We also consider pre-crisis government-debt-to-GDP ratio. Higher public debt may be associated with higher NPLs and longer NPL stabilization and resolution time, for two reasons. First, high public debt reduces the government's fiscal space, limiting its ability to cushion the fallout from the banking crisis fiscally. Second, high public debt may induce a sovereign-bank nexus where banks increase their domestic sovereign bond purchases due to government pressure or in a gamble for resurrection, thereby crowding out new credit to the private sector (Acharya et al. 2018; Ari, 2017).

We capture pre-crisis external conditions using the change in the bilateral nominal exchange rate against the U.S. dollar and two dummy variables for an exchange rate peg and for whether that peg was broken, all measured in the 5-year period prior to the crisis. Exchange rate flexibility may cushion the decline in economic activity during banking crises, helping stabilize and reduce NPLs. While a depreciation reduces the borrowers' ability to serve foreign currency denominated debts, it may still facilitate timely NPL resolution as currency mismatch-related losses to borrowers are typically easy to verify.

Institutional strength - in the form of robust corporate governance, rule of law, and an efficient legal system - may limit the increase in NPLs during a banking crisis and contribute to timely NPL resolution. We use a country's GDP per capita as a high-level proxy for institutional strength. Indicators for specific institutional factors are unavailable for many of the crises in the dataset.

The second specification adds predictors reflecting pre-crisis banking sector conditions. Most variables pertain to bank profitability: bank return on assets and equity, net interest margins, operating-expense-to-net-interest-income ratio, and noninterest-income-to-total-income ratio. Banks' cost efficiency and profitability may reflect low monitoring and high risk-taking and be associated with higher NPLs or reflect good management and imply lower NPLs (Berger and DeYoung, 1997). High profitability may also help banks absorb capital losses associated with NPL recognition, thus facilitating NPL resolution. We also include measures of bank concentration. A concentrated banking sector may better internalize the negative externalities of elevated NPLs on the wider economy, leading to lower peak NPLs and timelier resolution. Higher concentration may also make banks more profitable thus reducing their risk-taking incentives, leading to lower NPLs; or may have the opposite effect if banks are "too big to fail" (Kareken and Wallace, 1978; Keeley, 1990; Carletti, 2008). ${ }^{19}$ The second specification also

\footnotetext{
${ }^{19} \mathrm{We}$ cannot include bank capitalization directly as a predictor due to the lack of available data.
} 
includes the rule of law index from the World Bank Worldwide Governance Indicators (WGI) as an additional proxy of institutional strength.

The third and final specification adds predictors reflecting pre-crisis corporate conditions. We use the non-financial corporate debt-to-assets ratio to capture corporate leverage, earnings before interest and taxes (EBIT) to total interest expense ratio to capture corporate debt service capacity, the share of short-term debt in total debt, and current-asset-to-liability ratio to capture the maturity profile of debt and the rollover risk, and the share of foreign assets in total assets to capture international competitiveness. A more indebted corporate sector may experience higher NPLs, while a more internationally competitive corporate sector may be more resilient to adverse shocks, thereby reducing NPLs (Kalemli-Ozcan, Laeven, and Moreno, 2015). If firms are unable to roll over loans, however, shorter corporate debt maturities may induce faster recognition and stabilization of NPLs.

\section{c. Results}

Table 3 shows the results of the model selection analysis. The likelihood of elevated NPLs is lower in countries with higher GDP per capita and lower corporate debt (Panel A). Higher GDP per capita, a proxy for institutional strength, has strong predictive power in all three specifications. An increase in GDP per capita by one standard deviation reduces the likelihood of elevated NPLs by 27 to 50 percentage points depending on the specification..$^{20} \mathrm{~A}$ reduction in the corporate debt-to-assets ratio, reflecting stronger corporate sector conditions, by one standard deviation reduces the likelihood of elevated NPLs by 31 percentage points.

Conditional on elevated NPLs, peak NPLs are lower in countries with higher bank return on assets and longer corporate debt maturity (Panel B) - reflecting stronger banking and corporate sectors conditions. A one standard deviation increase in bank return on assets or in corporate debt maturity reduces peak NPL ratio by 5 and 4 percentage points, respectively.

A depreciation of the exchange rate against the USD by one standard deviation is associated with a sooner NPL peak of 10 to 14 months (Panel C). Abandoning an exchange rate peg prior to the crisis is also associated with sooner NPL peak. These results may reflect the cushioning effect of floating exchange rates in facilitating post-crisis macroeconomic adjustment. Also, pre-crisis depreciations may be indicative of an overall timelier policy response. Note, however, from Panel B, that depreciations and floating exchange rates do not predict lower peak NPLs, possibly due to currency mismatch-associated losses in firms and banks. ${ }^{21}$ NPLs peak sooner in countries with higher pre-crisis GDP growth, consistent with higher growth raising banks' and borrowers' debt management capacity. A one standard deviation increase in pre-crisis GDP growth reduces the time to peak by one year. NPLs also peak sooner in countries with lower pre-crisis government-debt-to-GDP ratio, reflecting more fiscal space. One standard deviation lower government debt reduces time to peak by approximately a year.

\footnotetext{
${ }^{20} \mathrm{We}$ standardize the candidate predictors data to Z-scores (i.e. zero mean and unit standard deviation across banking crises).

${ }^{21}$ Our results are robust to interacting exchange rate depreciations with proxies for currency mismatches, including corporate foreign assets and deposit dollarization (Yeyati, 2006).
} 
In contrast, NPLs peak later in countries with higher pre-crisis domestic credit growth. This may reflect the adverse impact of credit booms. An one standard deviation increase in domestic credit growth lengthens time to peak by approximately 9 months. Also, NPLs peak later in countries with higher longer debt maturity. A one standard deviation increase in corporate debt maturity extends time to peak by 6 months. Together with the results in Panel B, this implies that short-term corporate debt leads to faster NPL stabilization but higher peak NPLs. ${ }^{22}$

NPLs are resolved sooner, and the likelihood of NPL resolution is higher, in countries with lower pre-crisis government debt and credit growth, consistent with credit boom risks and fiscal space constraints (Panels D and E). One standard deviation lower pre-crisis government debt shortens the resolution time by over a year and increases the likelihood of NPL resolution by 15 percentage points. Similarly, one standard deviation lower credit growth reduces resolution time by 9 to 16 months and increases the likelihood of NPL resolution by 29 percentage points.

The likelihood of NPL resolution is higher in countries with higher growth, consistent with higher growth raising banks' and borrowers' debt management capacity. A one standard deviation increase in pre-crisis GDP growth raises the likelihood of NPL resolution by 12 percentage points. Moreover, the likelihood of NPL resolution is higher after exchange rate depreciation, consistent with floating exchange rates facilitating macroeconomic adjustment. Notably, exchange rate epreciation is the predictor with the strongest marginal effects: a one standard deviation larger depreciation against the USD increases the likelihood of NPL resolution by over 32 percentage points. The likelihood of NPL resolution is also higher when unemployment rises faster, possibly due to the pressure to resolve the debt sooner under a deteriorating labor market. A one standard deviation faster rise in pre-crisis unemployment rate is associated with an increase likelihood of NPL resolution by 11 to 12 percentage points.

The likelihood of NPL resolution is also lower in countries with better pre-crisis corporate liquidity, possibly because liquid assets held by borrowers reduce banks' incentives to write off debt. A one standard deviation increase in corporate current-asset-to-liability ratio reduces the likelihood of NPL resolution by 12 percentage points. Finally, the likelihood of NPL resolution is higher in countries with high bank non-interest-income-to-total-income ratio, which is a proxy for profitability and good management. A one standard deviation higher noninterest-to-total-income ratio increases the likelihood of NPL resolution by 15 percentage points.

Overall, we thus establish a set of pre-crisis macroeconomic, institutional, banking and corporate sector conditions that are predictive of NPL evolution during a banking crisis. The (pseudo) adjusted $\mathrm{R}^{2}$ values range from 0.42 to over 0.86 in regressions explaining the likelihood of elevated NPLs, 0.11 to 0.14 in regressions explaining peak NPLs, 0.03 to 0.23 in

\footnotetext{
${ }^{22}$ In specification (2), GDP per capital is positively associated with a longer time to peak. In specification (3), GDP per capita is no longer selected when corporate conditions are controlled for. These results may reflect higher corporate debt maturity in more developed countries.
} 
regressions explaining time to peak, 0.06 to 0.12 in regressions explaining resolution time, and 0.16 to 0.28 in regressions for the likelihood of NPL resolution.

We subject the model selection exercise to a number of robustness tests. In the first robustness test, we augment our specifications with crisis wave fixed effects, as the contemporaneous crises may share similar features. Appendix Table C4 shows the results. The selected predictors are identical for the likelihoods of elevated NPLs and of successful NPL resolution, while additional predictors are selected for peak NPLs and the resolution time, and fewer predictors are selected for time to peak.

In the second robustness test, we consider alternative definitions of the NPL dynamics measures. We use a 5 percent (instead of 7 percent) threshold for elevated NPLs, measure peak NPLs as a multiple of NPLs at the crisis date (instead of their percentage value), measure time to resolve NPLs relative to the year when they first exceed 7 percent (instead of the crisis year), and consider NPLs to be resolved if they fall below 25 percent of peak NPLs (instead of the 7 percent threshold). We compare the predictors selected under the baseline and alternative definitions in Table 4 (Appendix Table C5 shows the full results). Some patterns emerge from this comparison. First, there is substantial overlap between the predictors under the baseline and the alternative definitions. This offers comfort on the robustness of the baseline predictors. ${ }^{23}$ Second, the predictive powers are generally higher under the baseline definitions, suggesting the relative superiority of the baseline definitions from a forecasting perspective. Finally, the finding that the likelihood of elevated NPLs can be explained by a high degree of accuracy, and other aspects of NPL dynamics with a more modest degree of accuracy indicators carries over when using alternative definitions of NPL dynamics.

Overall, the model selection results suggest that NPL risk monitoring based on a limited set of high-level macroeconomic, institutional, and banking and corporate sector indicators is feasible.

\section{APPliCATION: NPLS IN THE European CRISIS COUNTRIES}

Our analysis so far has offered a number of stylized facts about NPL dynamics and identified a set of predictors. In this section, we discuss the NPL dynamics in European crisis countries in historic context. We ask to which extent the NPL dynamics in those countries could have been anticipated, and whether NPL resolution has been on par with international experience. To answer these questions, we use our model selection estimates (Section IV) to make out-ofsample predictions of the post-GFC NPL dynamics in European crisis countries and compare these predictions to actual outcomes.

\footnotetext{
${ }^{23}$ Robust predictors include, for the likelihood of elevated NPLs, GDP per capita and corporate debt-to-asset ratio; for time to peak, the exchange rate regime (depreciation or peg); for time to resolve, government debt-toGDP ratio; for the likelihood of NPL resolution, change in domestic credit to private sector, government debt-toGDP ratio (in level or change), the exchange rate (depreciation or peg), bank noninterest-income-to-total-income ratio, and corporate current-asset-to-liability ratio.
} 
Figure 9 plots the predictions for NPL dynamics and compares them with the actual outcomes for a group of European crisis countries with elevated NPLs. ${ }^{24}$ Panel A shows predicted average peak NPLs of 7.1 percent. While this indicates NPLs are at an elevated level, it is substantially lower than the actual 19.9 percent. Panel B shows that predicted time to peak is also shorter than actual: 2.5 years versus 5.6 years. In contrast, predicted time to resolution and resolution likelihood are close to the actual outcomes. Predicted time to resolve is 8.7 years, slightly higher than the actual 7.9 years (Panel C; note that actual time to resolve is truncated at 8 years while predicted time to resolve is not). Predicted resolution likelihood is 23 percentimplying 1 or 2 out of the 7 countries will resolve NPLs within 7 years - compared to the actual 14 percent, as 1 out of 7 countries resolved NPLs within 7 years.

Thus, our results suggest that slow NPL resolution in European crisis countries could have been anticipated based on historic crisis experiences and pre-crisis conditions. Yet the magnitude of peak NPLs was higher and the time to peak longer than what historic experience could have suggested. What drives these results?

For the two NPL outcomes that the data predict the best: time to resolution and resolution likelihood, the main identified risk factor is pre-crisis credit boom (measured by the change in domestic credit to private sector). This confirms the emphasis on credit booms (and more broadly balance of payments imbalances) as causes of the European crisis (Brunnermeier and Reis, 2019). The imprecision of the time to peak prediction is likely attributable to the fact that although the crisis in Europe started during the GFC in 2008, it intensified in several countries in 2011-2013 due to sovereign debt distress that spilled over to the banking sector (Acharya et al. 2018). We follow the crisis start dating in Laeven and Valencia (2013, 2018). Recognizing a banking crisis around 2012 would bring the predicted time-to-peak closer to its actual value. 25

As for peak NPLs, the key variable that drives the wedge between its actual and predicted value for European crisis countries is GDP per capita. In our analysis, we treat GDP per capita, among other interpretations, as a proxy for institution strength. Pre-GFC experience suggests that a strong institutional environment helps to arrest the rise in NPLs. Yet this was not the case in European crisis countries despite their high GDP per capita being in the $90^{\text {th }}$ percentile in our sample. Our analysis thus suggests that the contrast between a relatively strong institutional environment and a large increase in NPLs is, from a historical perspective, a key surprise regarding the NPL dynamics in the European crisis countries. ${ }^{26}$

\footnotetext{
${ }^{24}$ The sample include Greece, Ireland, Italy, Portugal, Spain, Hungary, and Slovenia. The predictions report averages across the countries, and use the macroeconomic conditions specification. Using the banking and corporate specification will reduce the number of observations for estimation and reduces the precision.

25 A sovereign debt crisis started in Greece in 2012 (Laeven and Valencia, 2018).

${ }^{26}$ To replicate the actual value of NPLs in the European crisis countries in our model, we would need to set GDP per capita to below the mean.
} 


\section{CONCLUSION}

The GFC highlighted the impact of elevated NPLs on the economy and the challenges of NPL resolution. A decade after the GFC, the risk of NPLs remains acute in view of leverage-related vulnerabilities in many countries. However, our understanding of NPL dynamics during banking crises is often constrained by data limitations.

Against this background, this paper introduces and analyzes a new dataset on NPL dynamics in 88 banking crises since 1990s. We find that NPLs during banking crises are on average higher and more volatile than NPLs in normal times. A large majority of banking crises had elevated NPLs. While there are many cross-country commonalities in the trajectories of NPLs, there is also much heterogeneity in NPL resolution.

We document new evidence on the close relationship between post-crisis NPLs and output growth. NPL problems - elevated and unresolved NPLs - are associated with more severe post-crisis recessions. These findings point to the importance of understanding "risk factors" associated with adverse NPL dynamics (high NPLs and slow resolution). We identify key risk factors including high credit growth, high government debt, fixed exchange rates and high corporate debt with short maturity. These findings suggest that sound ex ante macroeconomic and macro-prudential policies can play an important role in preventing NPL problems during banking crises. Notably, monetary and prudential policies can help curb excessive credit growth and limit bank risk taking, while prudent fiscal policies can create the fiscal space needed for crisis interventions and help avoid a negative sovereign-bank loop. Exchange rate flexibility can also help cushion real and financial shocks and support the economic recovery. Finally, strong institutions can help ensure robust corporate governance, effective supervision and regulation of banks and create a legal environment that facilitates NPL resolution.

Reliable NPL data are vital for anticipating and gauging the extent of NPL problems and formulating policy responses. Although NPLs are common in many banking crises, there are significant gaps in data coverage especially for the pre-2000 period. While much progress has been made in collecting and publishing NPL data in many countries, cross-country comparisons are hampered by a lack of a harmonized NPL definition. Recent IMF (2006), European Banking Authority (ECB 2017), and Basel Committee on Banking Supervision (BCBS 2017) guidelines aim to promote such harmonization. Furthermore, bank-level NPL data are still limited to date except for large and publicly-listed banks. Granular bank- or loanlevel data are essential to advance our understanding of the causes of NPLs and of the effectiveness of policy interventions. Much research is still needed; and the new data presented in this paper may assist such research. 


\section{References}

Accornero, Matteo, Piergiorgio Alessandri, Luisa Carpinelli, and Alberto Maria Sorrentino, 2017, "Non-performing loans and the supply of bank credit: evidence from Italy", Bank of Italy Occasional Paper Series, 374.

Acharya, Viral V., Eisert, Tim, and Christian Eufinger, Christian Hirsch, 2018, "Real Effects of the Sovereign Debt Crisis in Europe: Evidence from Syndicated Loans", The Review of Financial Studies, 31(8): 2855-2896.

Aiyar, Shekhar, Wolfgang Bergthaler, Jose M. Garrido, Anna Ilyina, Andreas (Andy) Jobst, Kenneth Kang, Dmitriy Kovtun, Yan Liu, Dermot Monaghan, and Marina Moretti, 2015, “A Strategy for Resolving Europe's Problem Loan,” IMF Staff Discussion Note 15/19, International Monetary Fund, Washington.

Ari, Anil, 2017, "Sovereign Risk and Bank Risk-Taking," IMF Working Paper, WP/17/280

Balgova, Marta, Alexander Plekhanov, and Marta Skrzypinska, 2017, "Reducing nonperforming loans: Stylized facts and economic impact", mimeo.

Basel Committee on Banking Supervision, (BCBS), 2017, "Prudential Treatment of Problem Assets - Definitions of Non-Performing Exposures and Forbearance".

Belloni, Alexandre, Daniel Chen, Victor Chernozhukov, and Christian Hansen, 2012, "Sparse Models and Methods for Optimal Instruments with An Application to Eminent Domain", Econometrica, 80(6): 2369-2429.

Belloni, Alexandre, and Victor Chernozhukov, 2013, "Least Squares After Model Selection in High-Dimensional Sparse Models", Bernoulli, 19(2): 521-547.

Berger, Allen N., and Robert DeYoung, 1997, "Problem loans and cost efficiency in commercial banks," Journal of Banking and Finance, 21(6): 849-870.

Bhattacharya, Kaushik, 2003, "How good is the BankScope database? A cross-validation exercise with correction factors for market concentration measures." BIS Working Paper 133.

Brunnermeier, Markus K., and Ricardo Reis, 2019, "A Crash Course on the Euro Crisis," NBER Working Paper 26229.

European Central Bank (ECB), 2017, Guidance to Banks on Non-Performing Loans.

Ghosh, Amit, 2015, "Banking-Industry Specific and Regional Economic Determinants of Nonperforming Loans: Evidence from US States”, Journal of Financial Stability, 20: 93-104.

International Monetary Fund (IMF), 2006, Financial Soundness Indicators Compilation Guide, International Monetary Fund, Washington. 
International Monetary Fund (IMF), 2016, "Fostering Stability in a Low-Growth, Low-Rate Era," Global Financial Stability Report, October, Chapter 1, International Monetary Fund, Washington.

International Monetary Fund (IMF), 2019, "Vulnerabilities in a Maturing Credit Cycle," Global Financial Stability Report, October, Chapter 1, International Monetary Fund, Washington.

Jordà, Òscar. 2005. "Estimation and Inference of Impulse Responses by Local Projections", American Economic Review, 95 (1): 161-182.

Jordà, Òscar, Moritz Schularick, and Alan M. Taylor, 2013, "When Credit Bites Back", Journal of Money, Credit, and Banking, 45(2): 3-28.

Kalemli-Ozcan, Sebnem, Luc Laeven, and David Moreno, 2015, "Debt overhang, rollover risk and investment in Europe", mimeo.

Kaminsky, Graciela, L., and Carmen M. Reinhart, 1999, "The Twin Crises: The Causes of Banking and Balance-of-Payments Problems", American Economic Review, 89 (3): 473-500.

Laeven, Luc, and Fabian Valencia 2013, "Systemic Banking Crises Database", IMF Economic Review, 61(2): 225-270.

Laeven, Luc, and Fabian Valencia, 2018, "Systemic Banking Crises Revisited," IMF Working Paper, 18/206, International Monetary Fund, Washington.

McFadden, Daniel L, 1974, "Conditional logit analysis of qualitative choice behavior," pp. 105-142 in P. Zarembka (ed.), Frontiers in Econometrics. Academic Press.

Yeyati, Eduardo Levy, 2006, "Financial Dollarization: Evaluating the Consequences", Economic Policy, vol. 21(45): 61-118.

Podpiera, Jiří, and Laurent Weill, L., 2008, "Bad Luck or Bad Management? Emerging Banking Market Experience," Journal of Financial Stability, 4, pp.135-148.

Reinhart, Carmen M., and Kenneth S. Rogoff, 2009a, "The Aftermath of Financial Crises.American Economic Review," 99, pp. 466-72.

Reinhart, Carmen M., and Kenneth S. Rogoff, 2009b, "This Time Is Different: Eight Centuries of Financial Folly," Princeton, NJ: Princeton University Press.

Romer, Christina D. and David H. Romer, 2017, "New Evidence on the Aftermath of Financial Crises in Advanced Countries", American Economic Review, 107(10): 3072-3118. 
Figure 1: A typical NPL trajectory

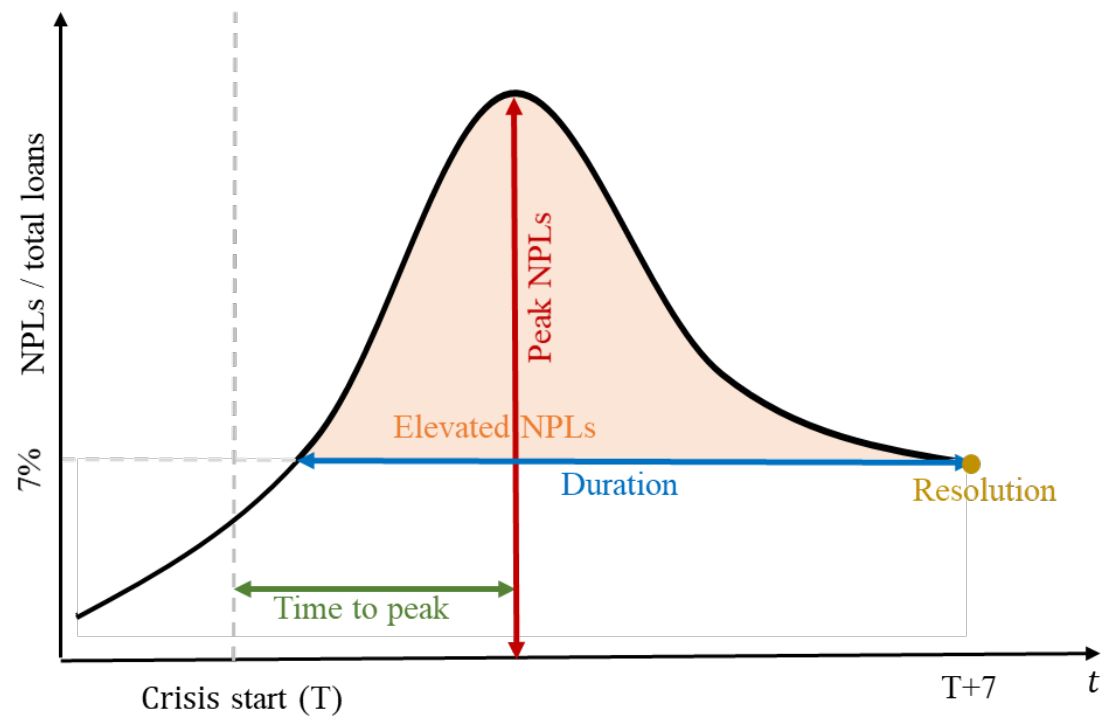

Source: Authors' calculations. 


\section{Figure 2: A new dataset on NPL dynamics}

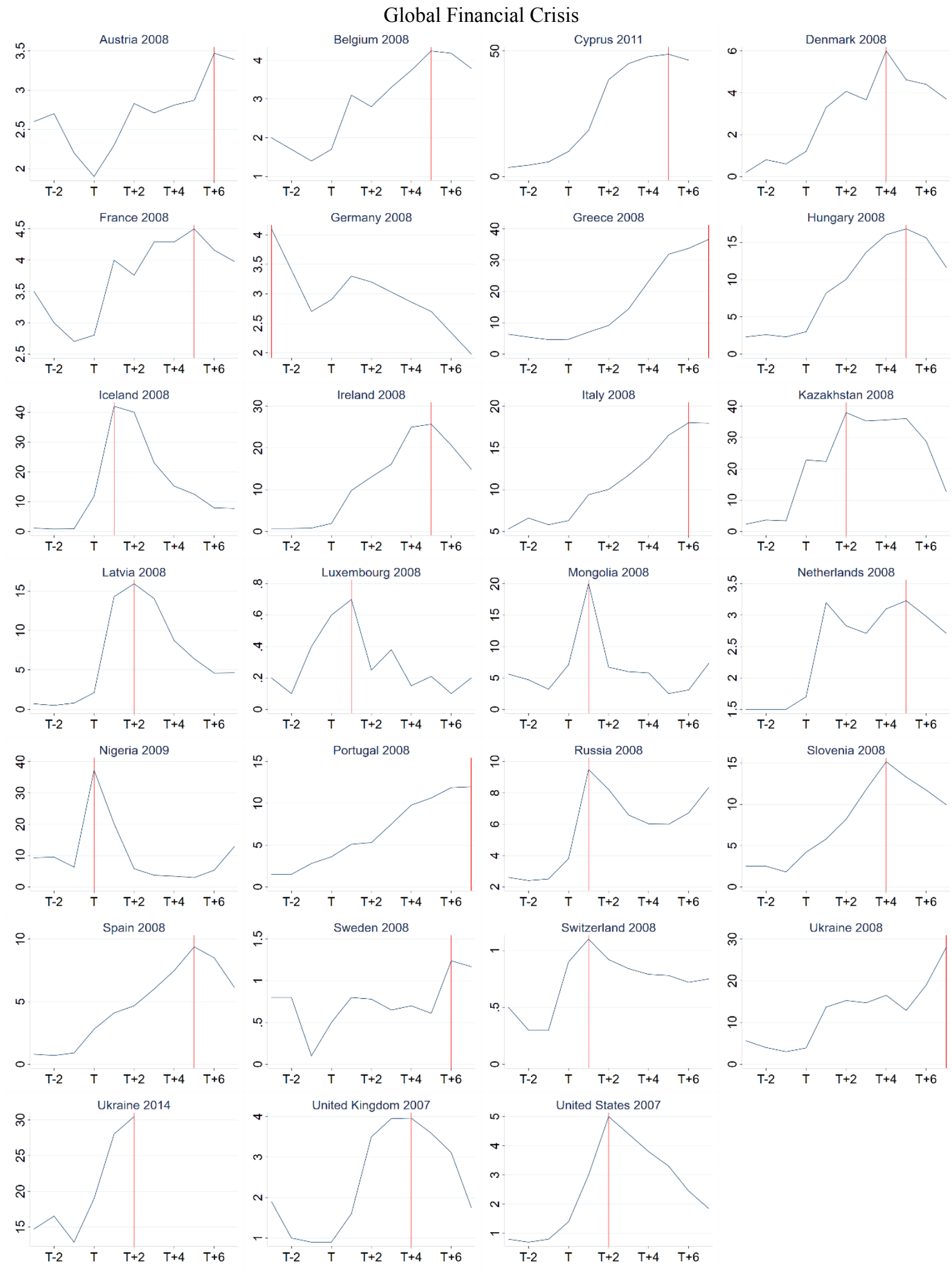




\section{Figure 2: A new dataset on NPL dynamics (cont')}
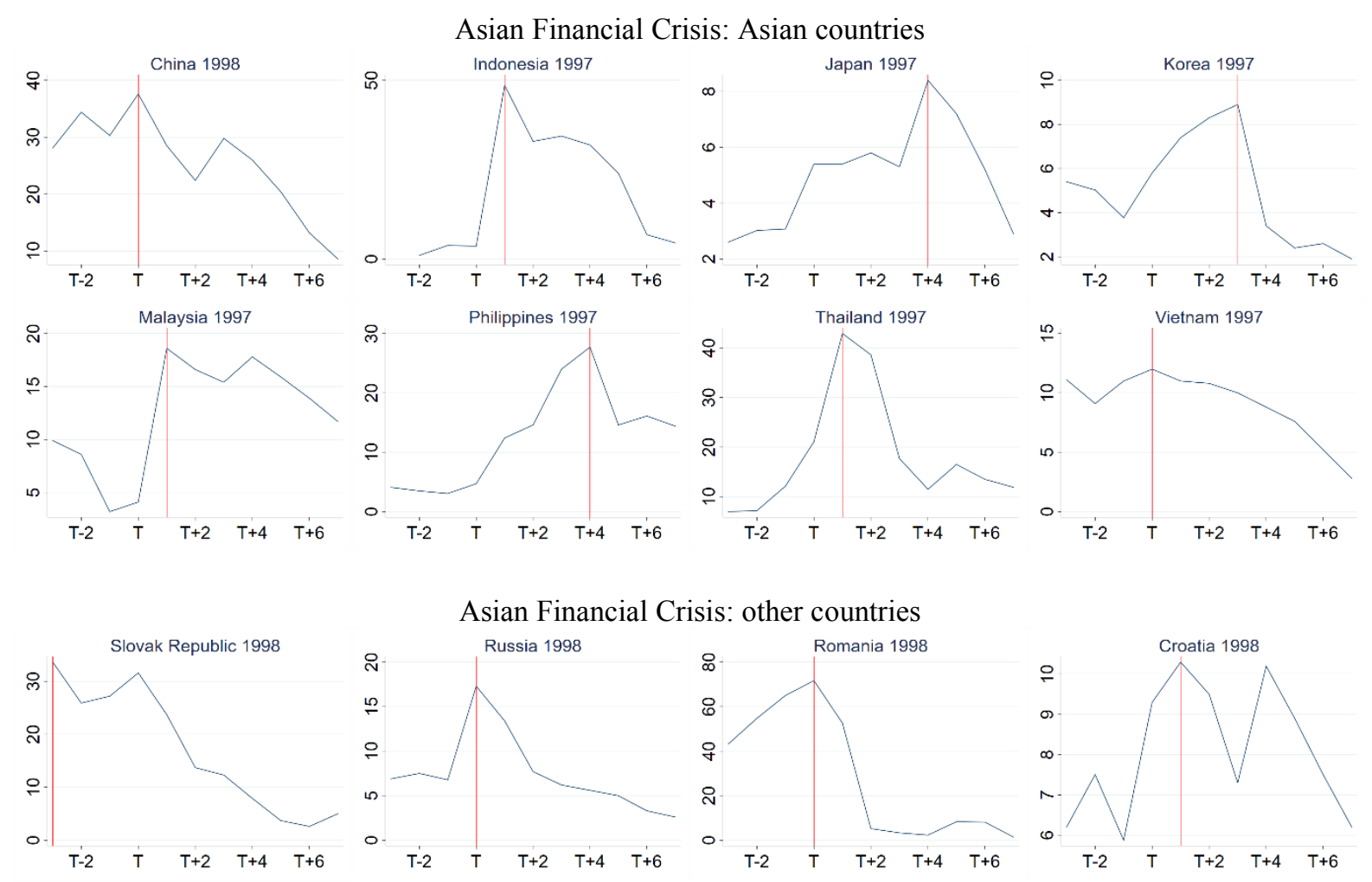

Asian Financial Crisis: other countries
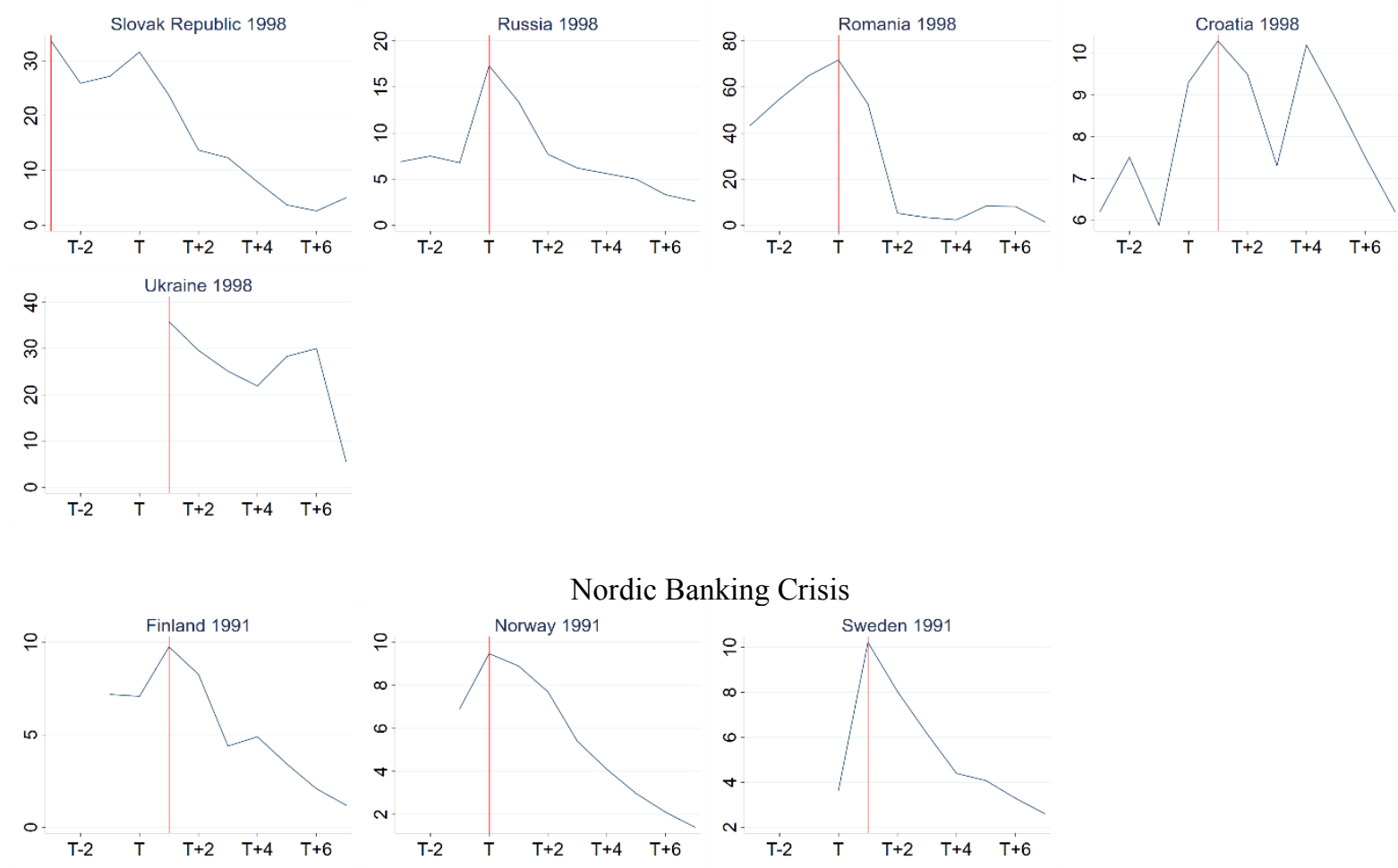


\section{Figure 2: A new dataset on NPL dynamics (cont')}
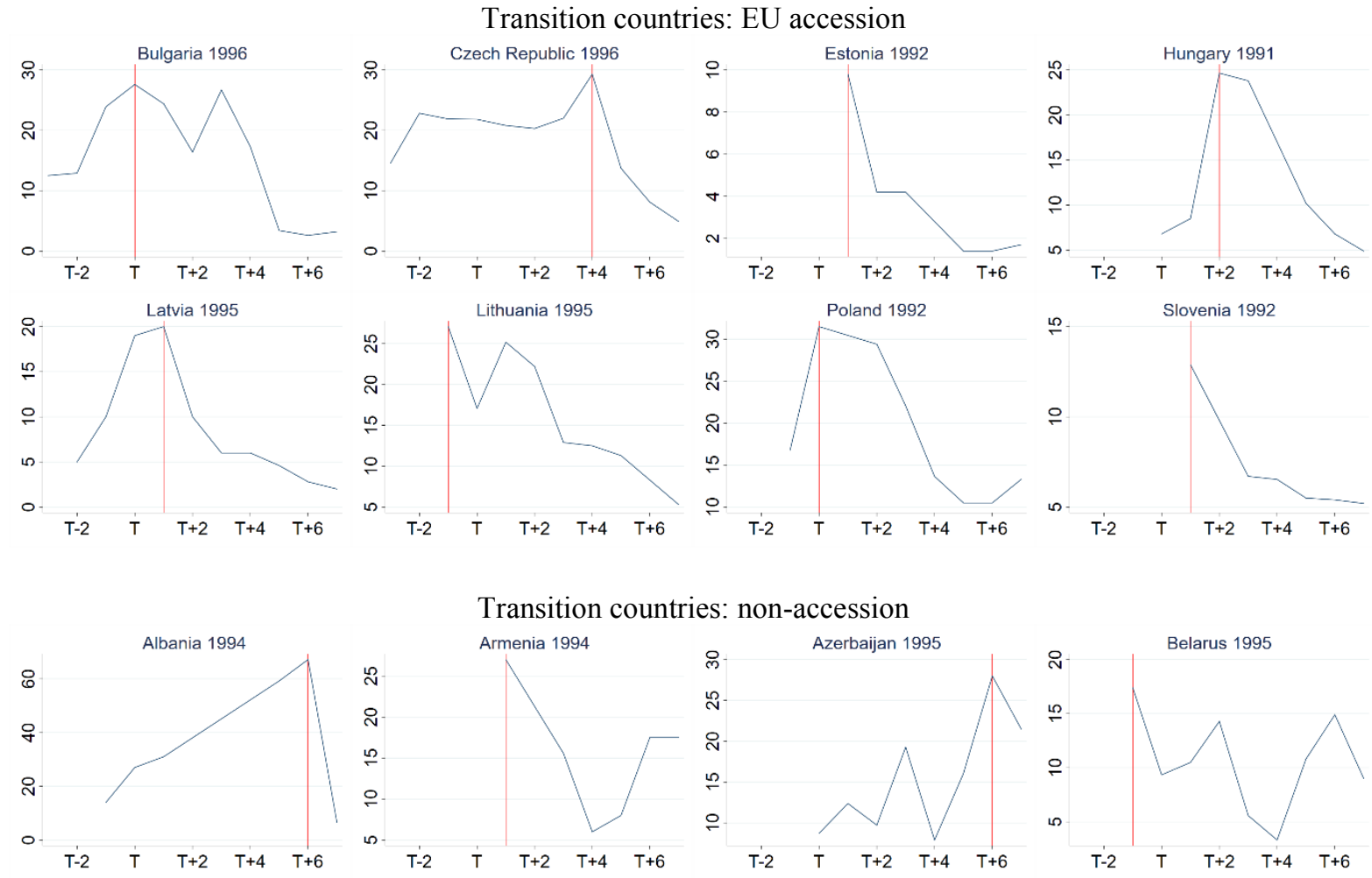

Transition countries: non-accession
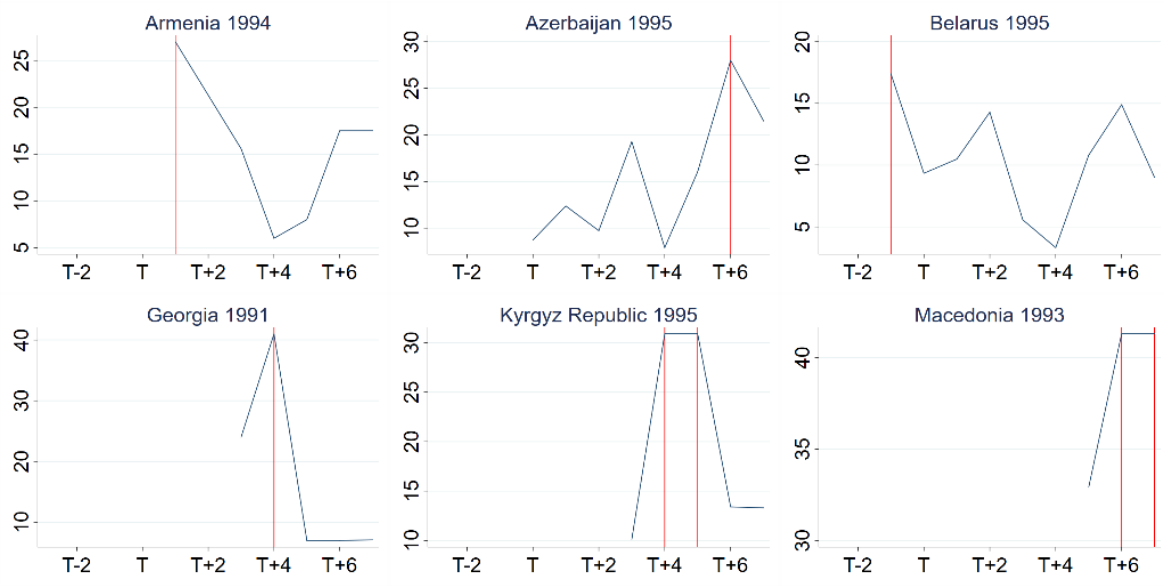
Figure 2: A new dataset on NPL dynamics (cont')

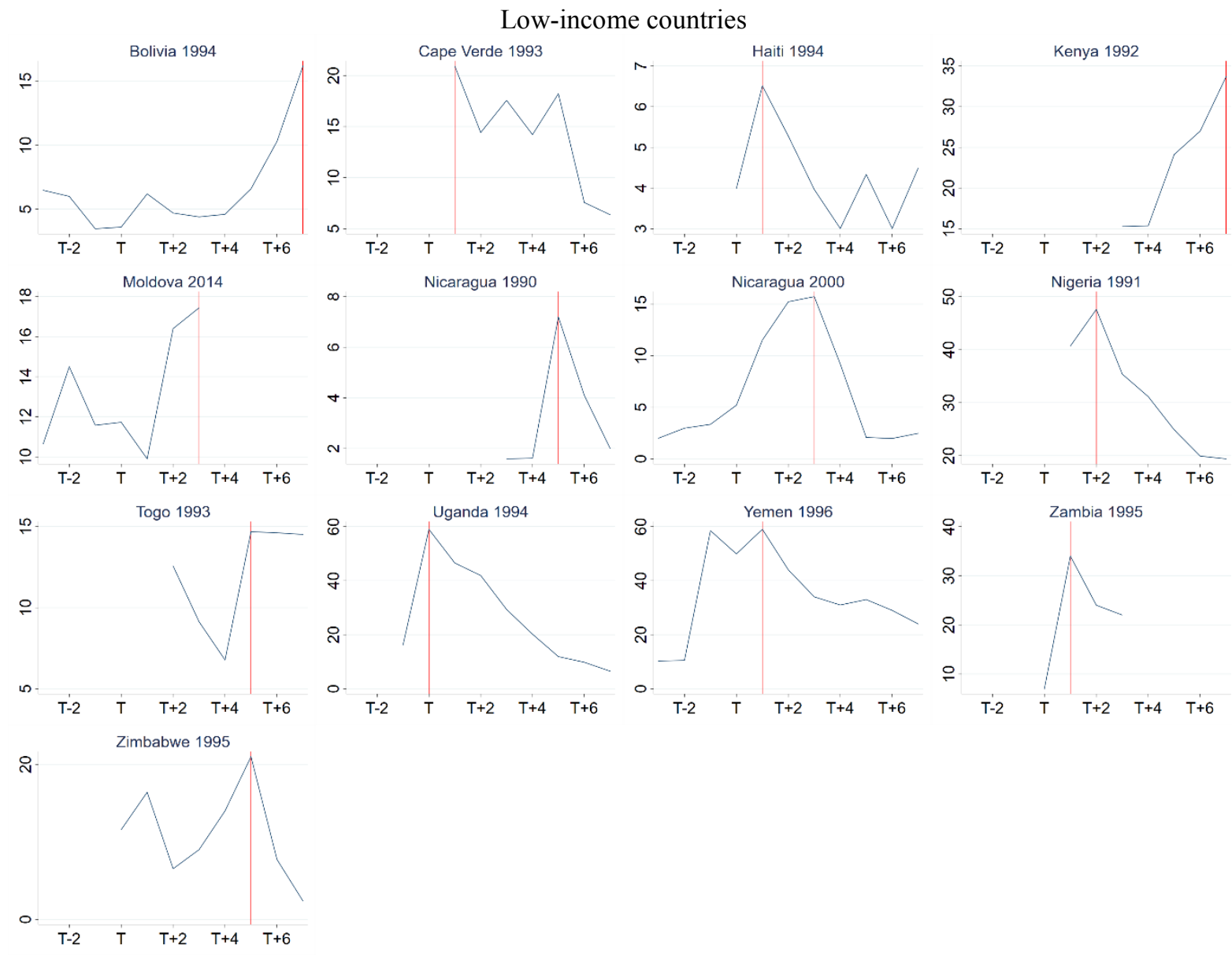




\section{Figure 2: A new dataset on NPL dynamics (cont')}

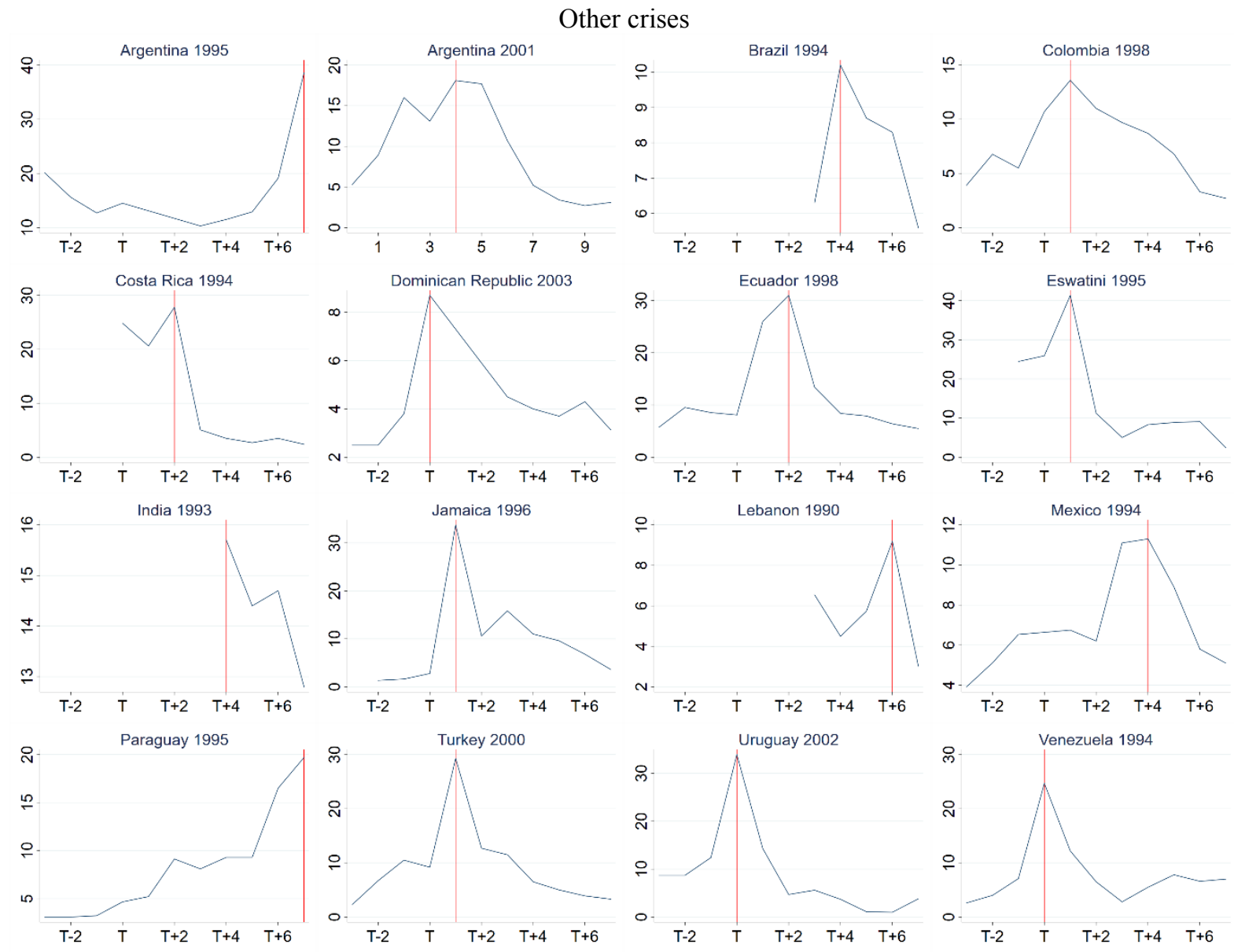

Note: T refers to the starting year of a banking crisis (Laeven and Valencia, 2013, 2018). The vertical axis plots NPL to total loans ratio (\%). The red line indicates the year with peak NPLs. Source: IMF FSI, IMF Staff Reports, Bankscope, national sources, and authors' calculations. 
Figure 3: NPLs during banking crises around the world

Panel A: Pre-crisis NPLs

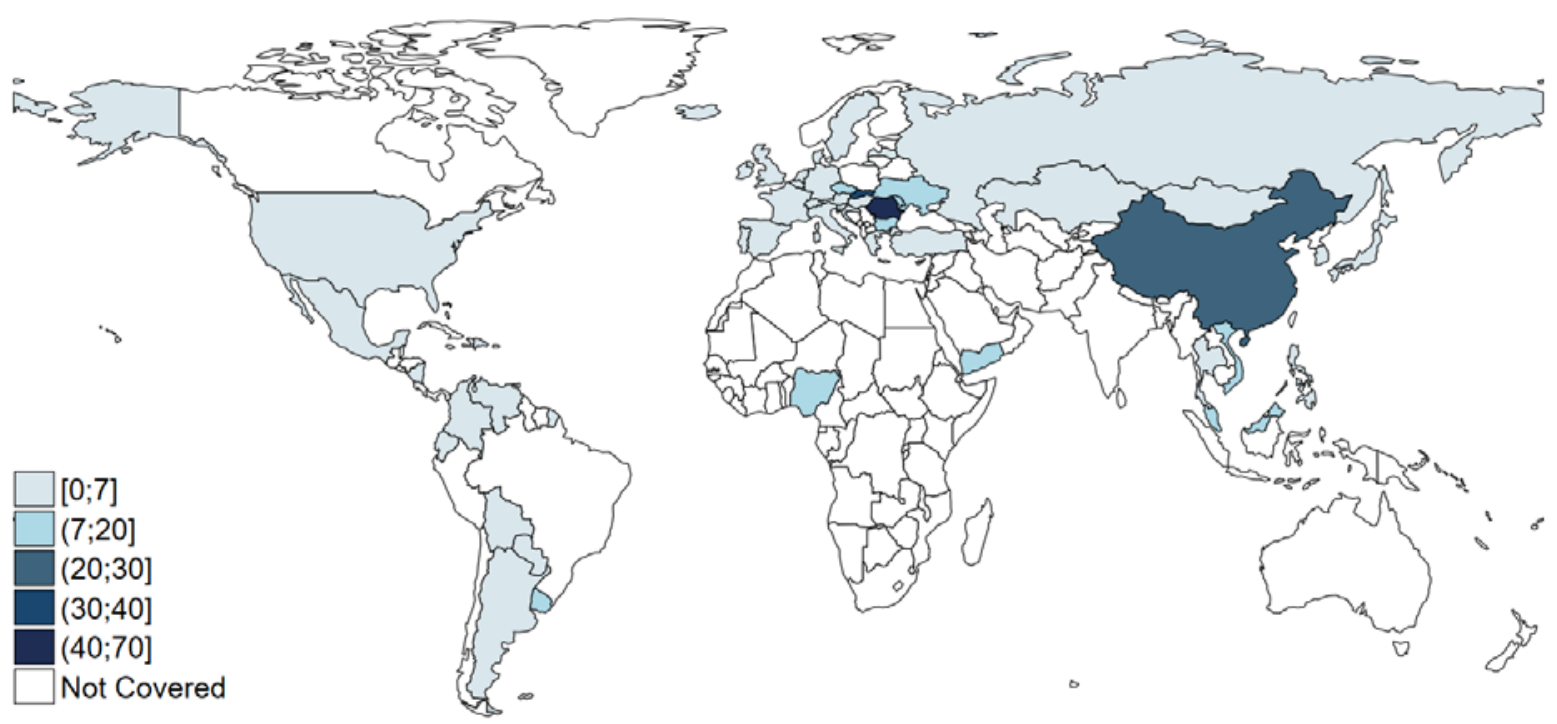

Panel B: NPLs in crisis start year

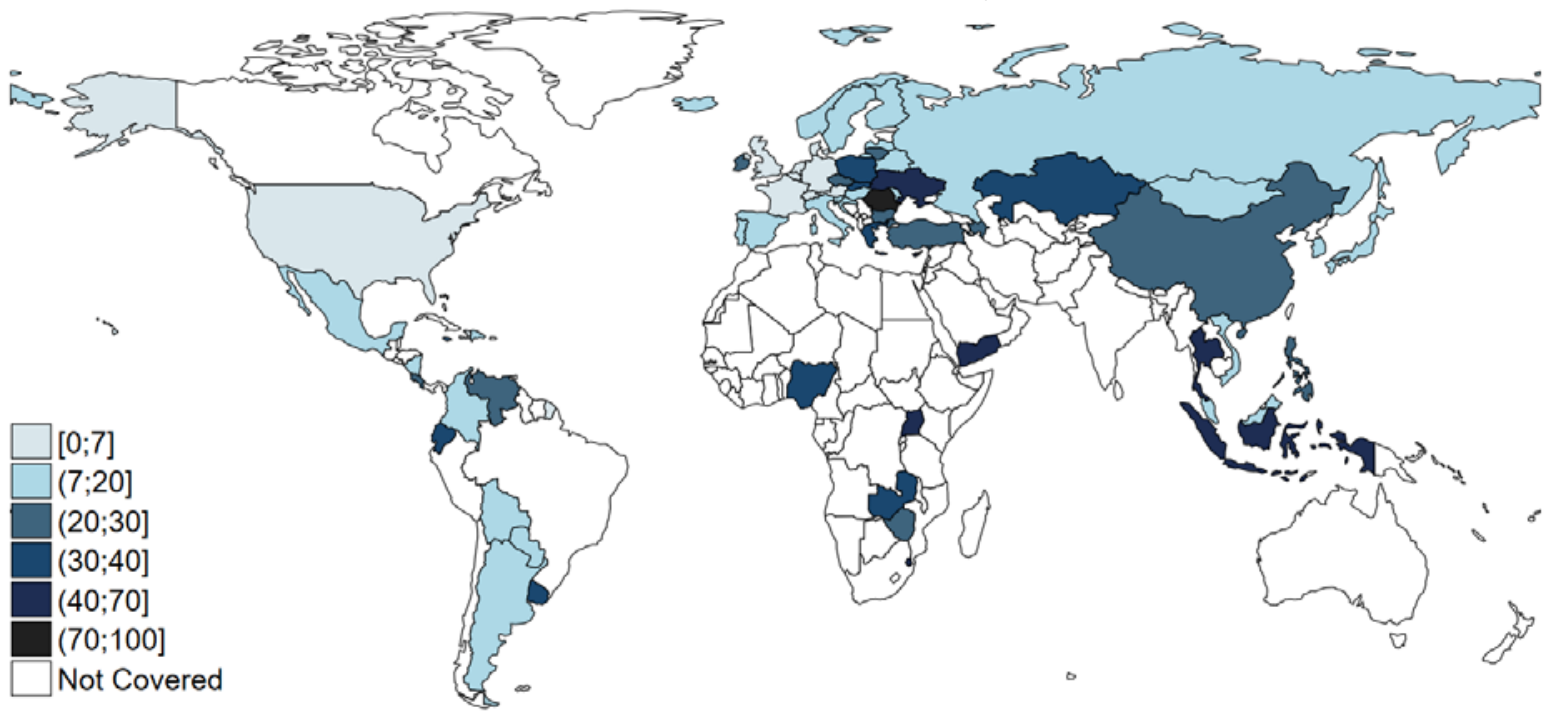


Figure 3: NPLs during banking crises around the world (cont')

Panel C: Peak NPLs

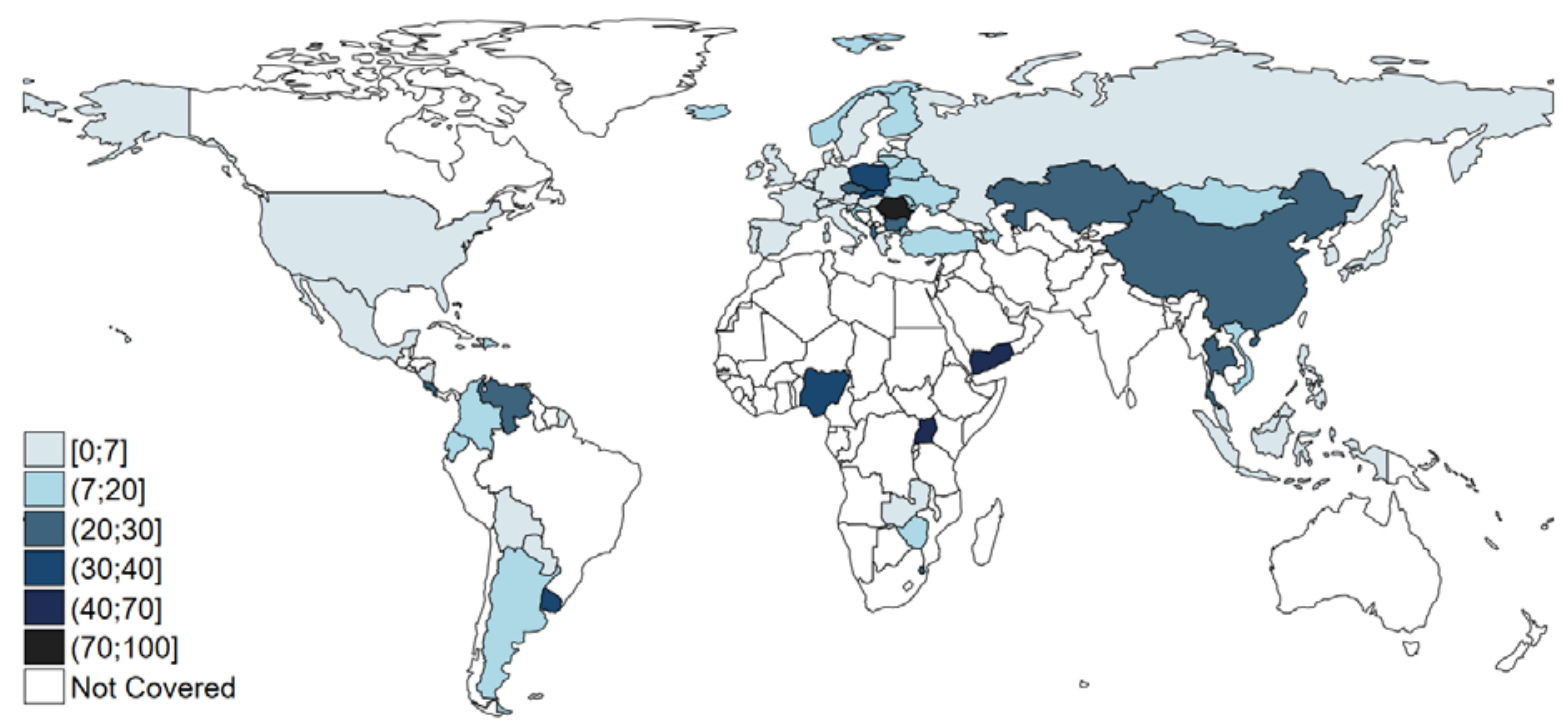

Panel D: NPLs 7 years after crisis start

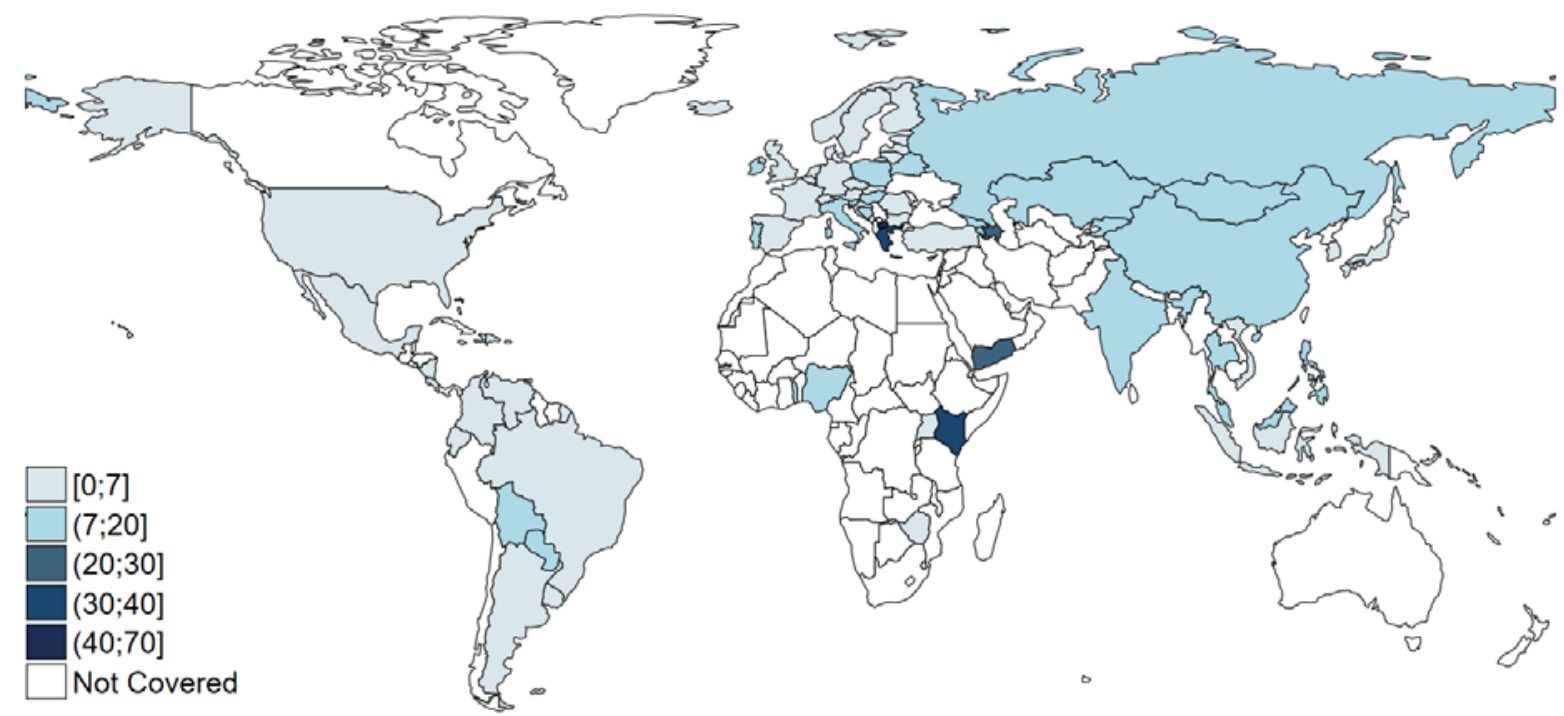

Note: This figure shows NPLs (as a percentage of total loans) 3 years before the start of a crisis (Panel A), in the crisis start year (Panel B), peak NPLs, and NPLs 7 years after the start of a crisis (Panel D).

Source: IMF FSI, IMF Staff Reports, Bankscope, national sources, and authors’ calculations. 


\section{Figure 4: Distribution of peak NPLs}

Panel A: Peak NPLs

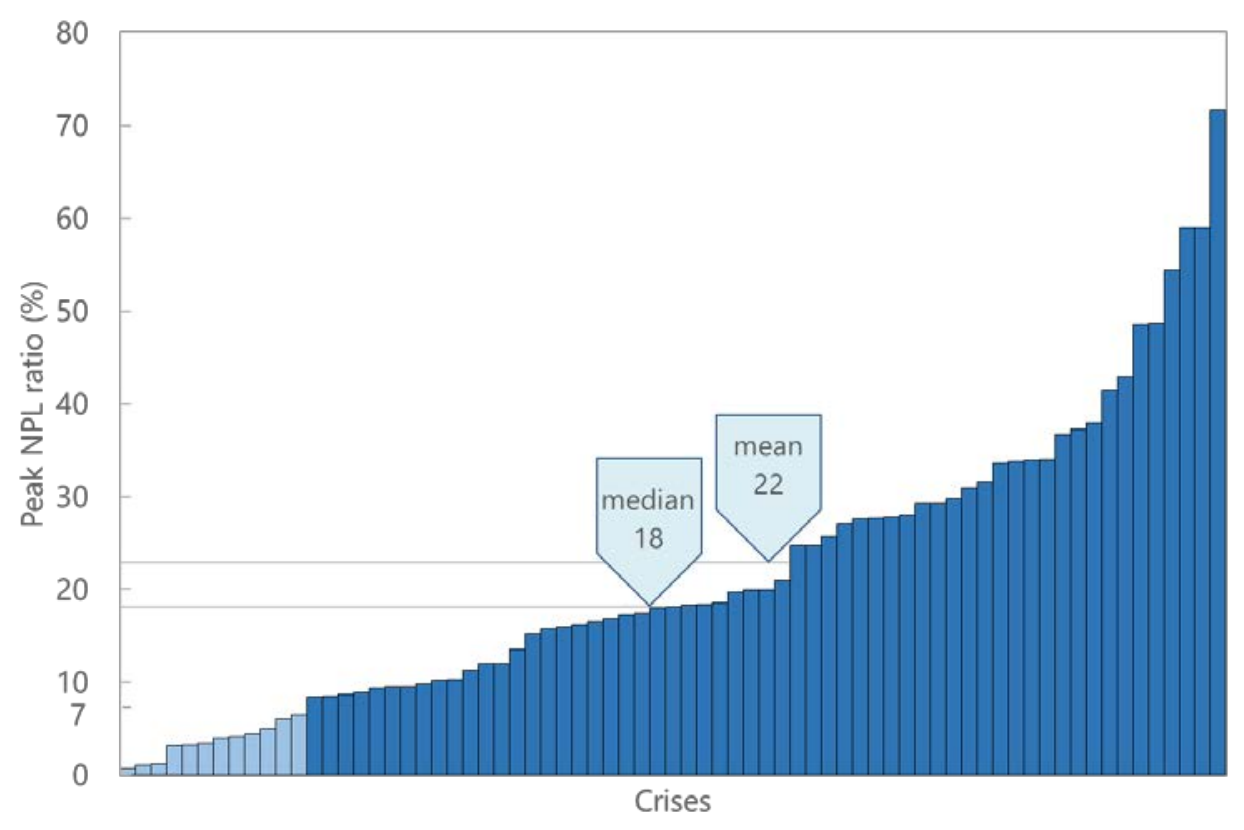

Source: IMF FSI, IMF Staff Reports, Bankscope, national sources, and authors' calculations.

Panel B: Peak NPLs relative to NPLs at crisis date

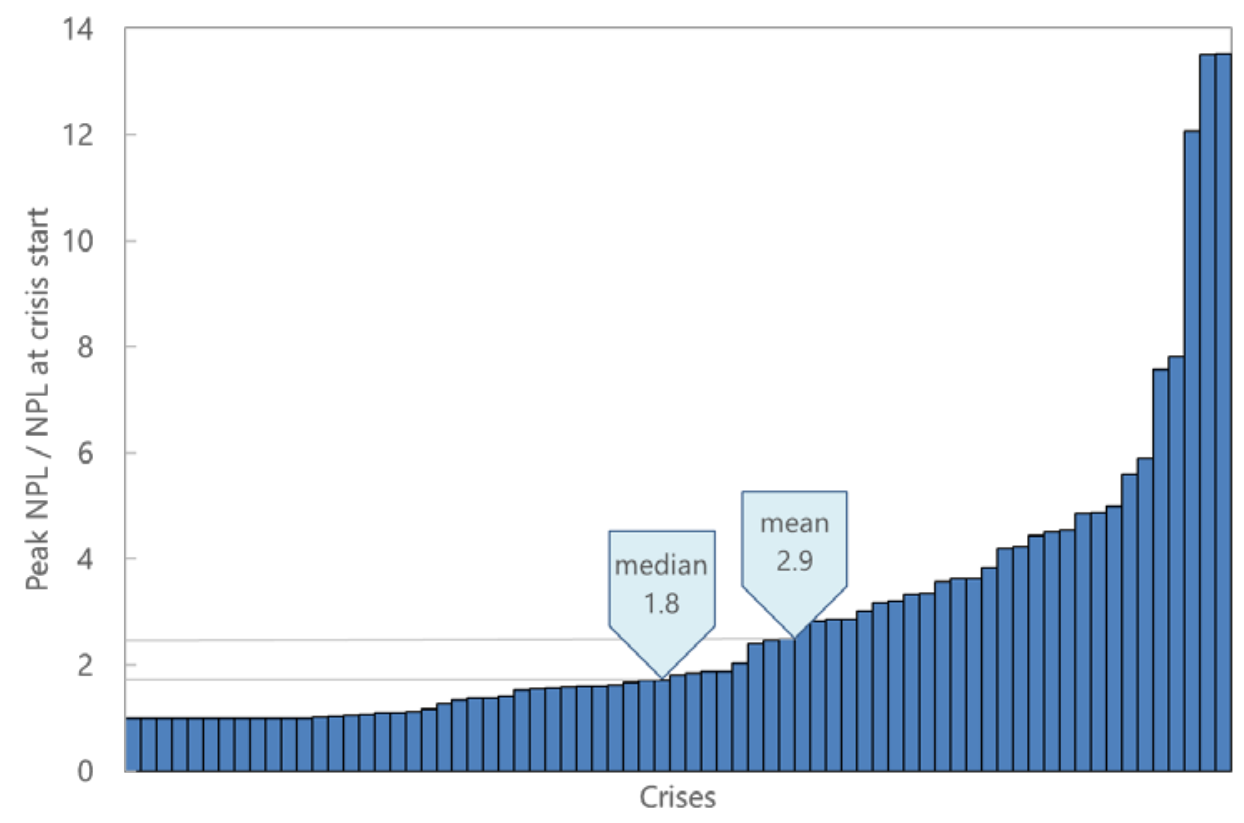

Source: IMF FSI, IMF Staff Reports, Bankscope, national sources, and authors' calculations. 
Figure 5: Time to peak

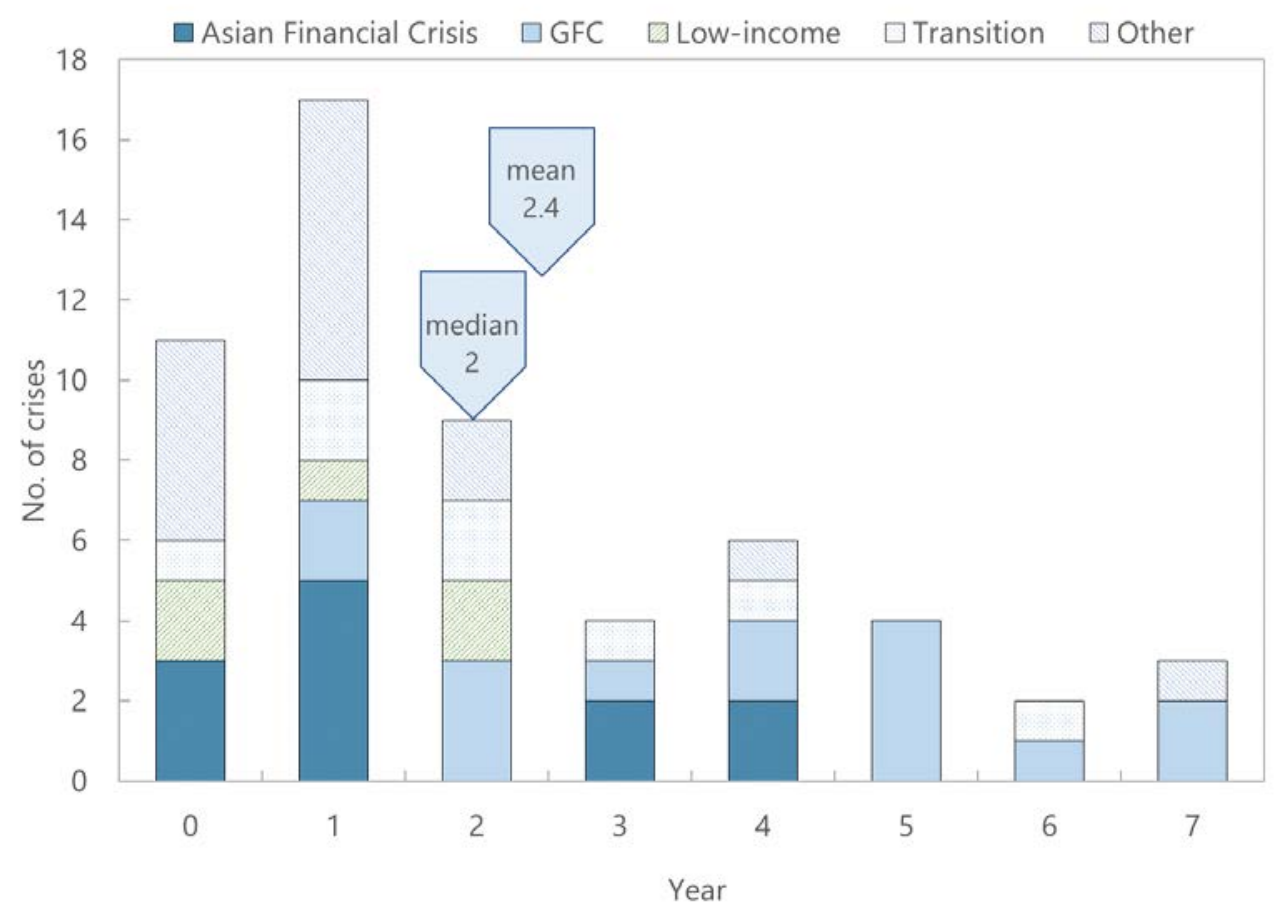

Figure 6: NPL resolution within 7 years

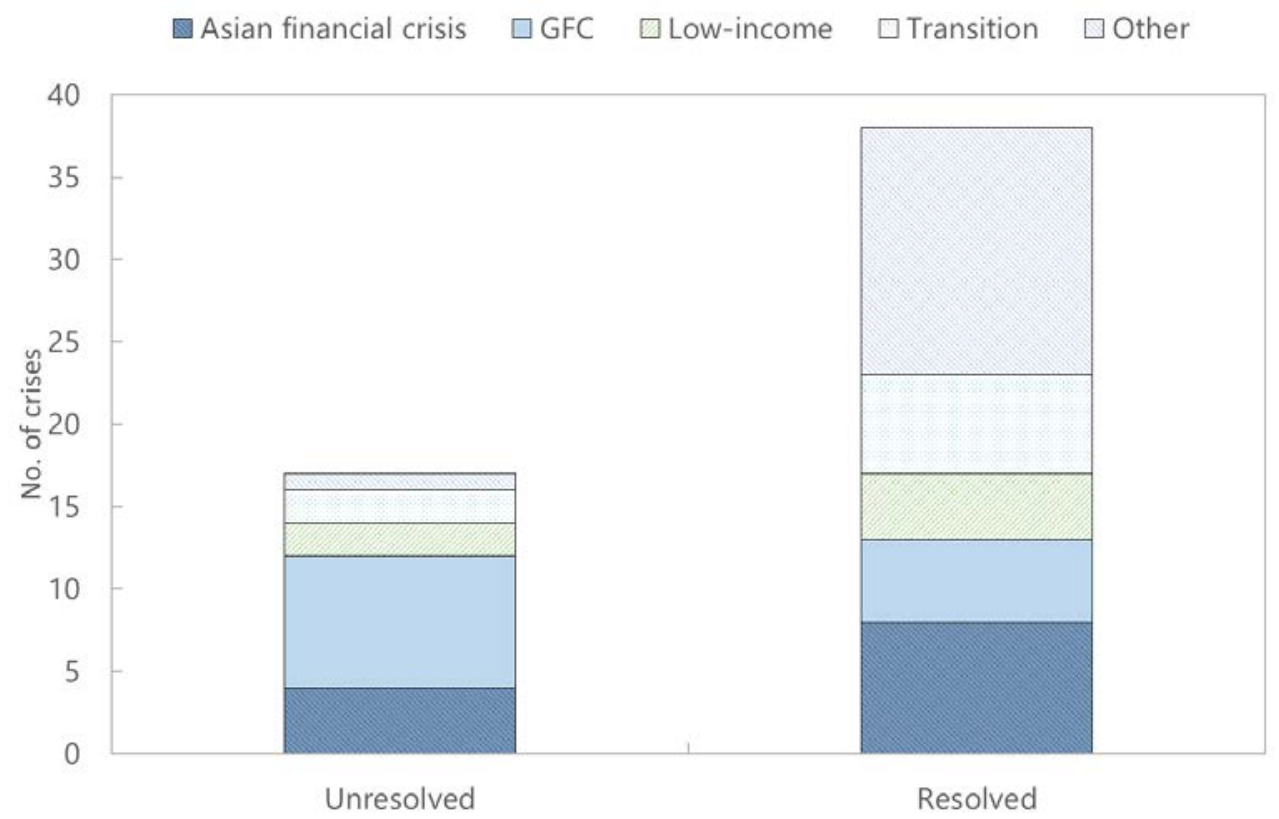

Source: IMF FSI, IMF Staff Reports, Bankscope, national sources, and authors' calculations. 


\section{Figure 7: Time to NPL resolution}

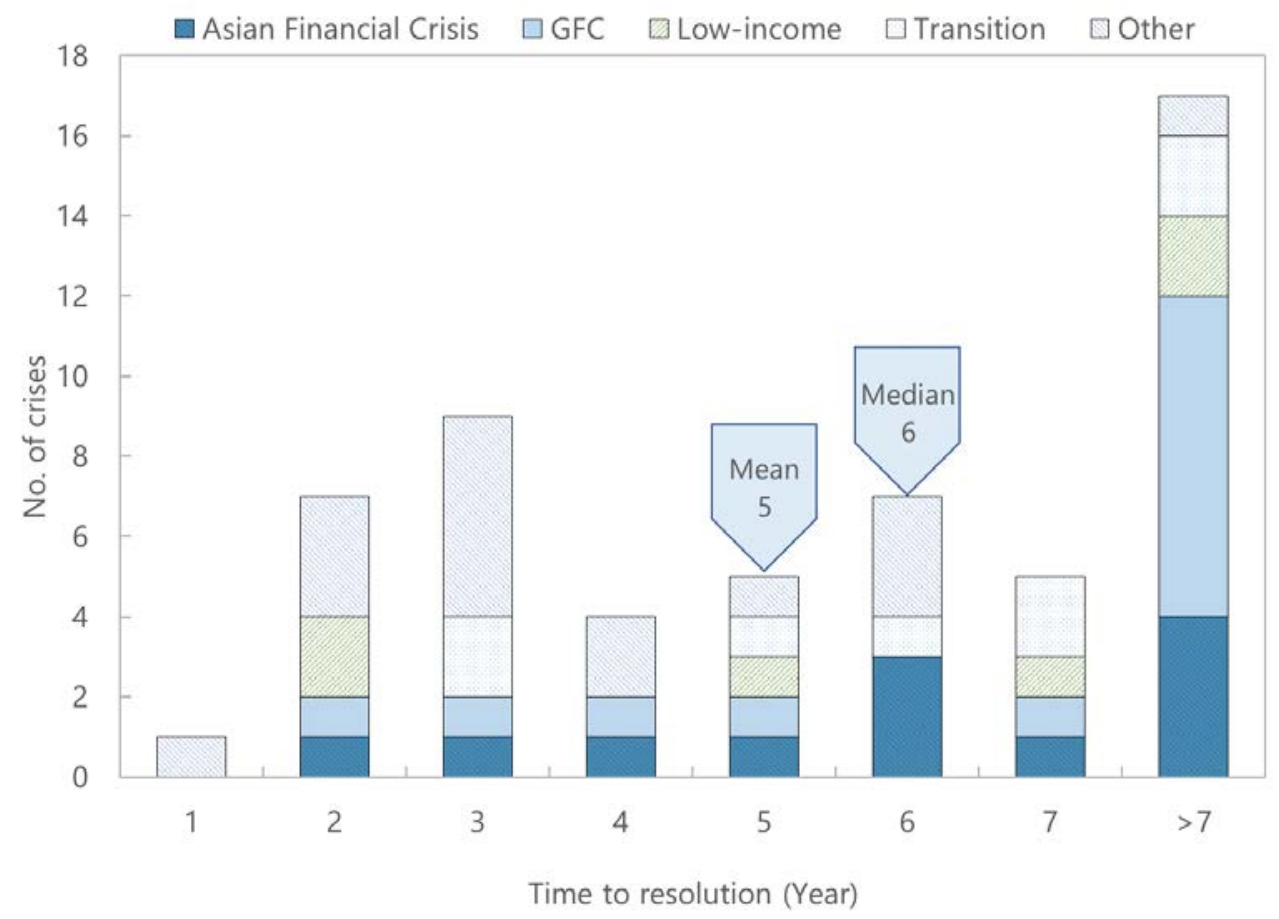

Source: IMF FSI, IMF Staff Reports, Bankscope, national sources, and authors' calculations. 
Figure 8: Output dynamics

Panel A: Output path and high NPLs

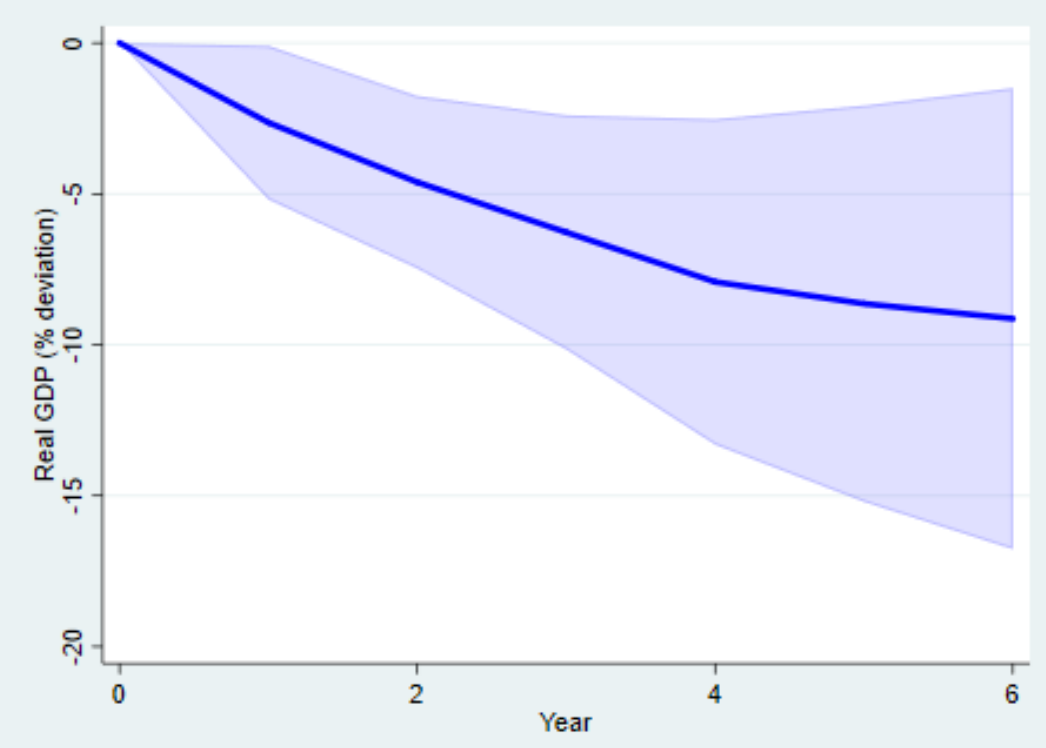

Panel B: Output path and NPL resolution

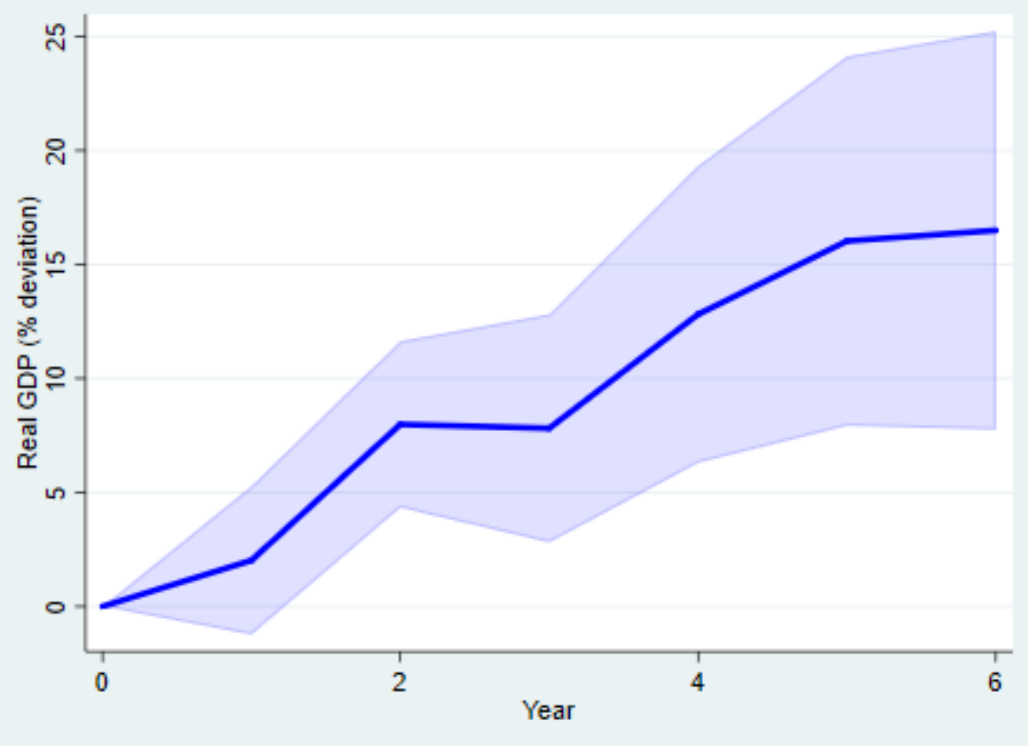

Notes: Panel A plots the coefficients of the average real GDP (in logarithm, relative to the crisis year, i.e. year zero, multiplied by 100) in crises with high NPLs relative to crises with elevated NPLs. Elevated NPLs is defined when NPLs are higher than 7 percent of total loans. Panel B plots the coefficients of the average real GDP (in logarithm, relative to the crisis year, i.e. year zero, multiplied by 100) in crises with resolved NPLs relative to crises with unresolved NPLs. NPL resolution is defined when NPLs fall below 7 percent of total loans, inclusive. Controls include crisis wave fixed effects, two lags of exchange rate, debt to GDP ratio, credit to the private sector (all measured in first difference), two lags of real GDP (in log first difference), and two lags of NPL to total loans ratio. The blue bar plots the 90 percent confidence interval. Source: Authors' estimations. 
Figure 9: European Crisis Experience

Panel A: Peak NPLs

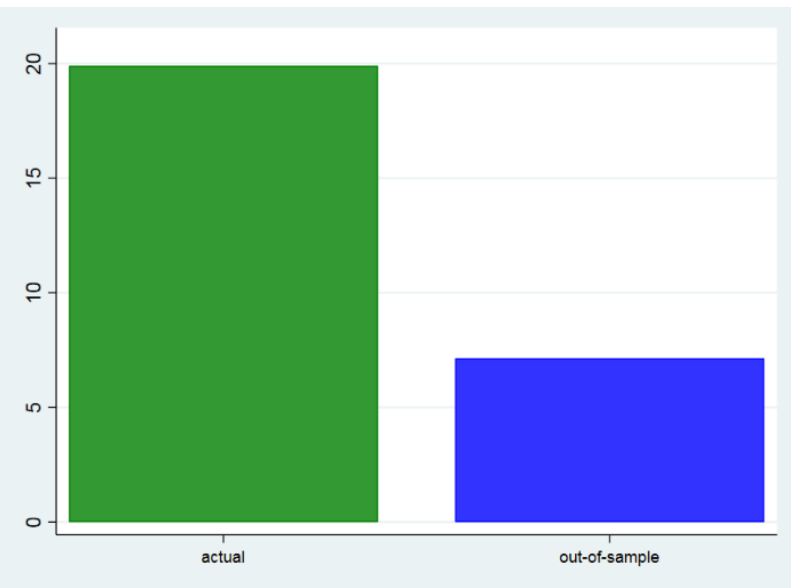

Panel C: Time to resolve

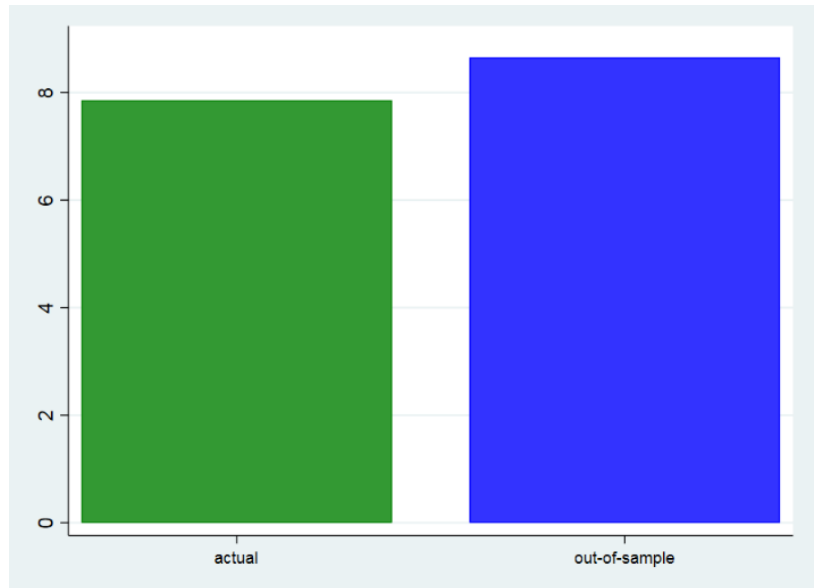

Panel B: Time to peak

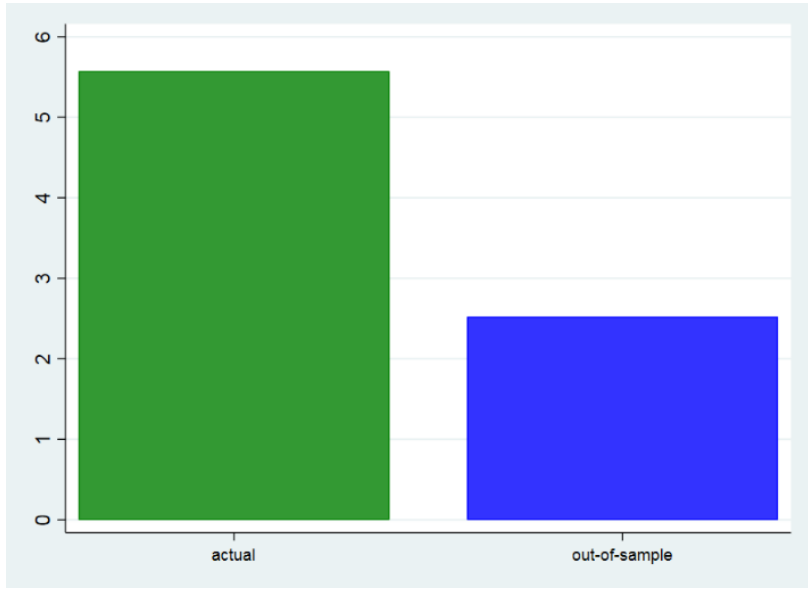

Panel D: NPL resolution probability

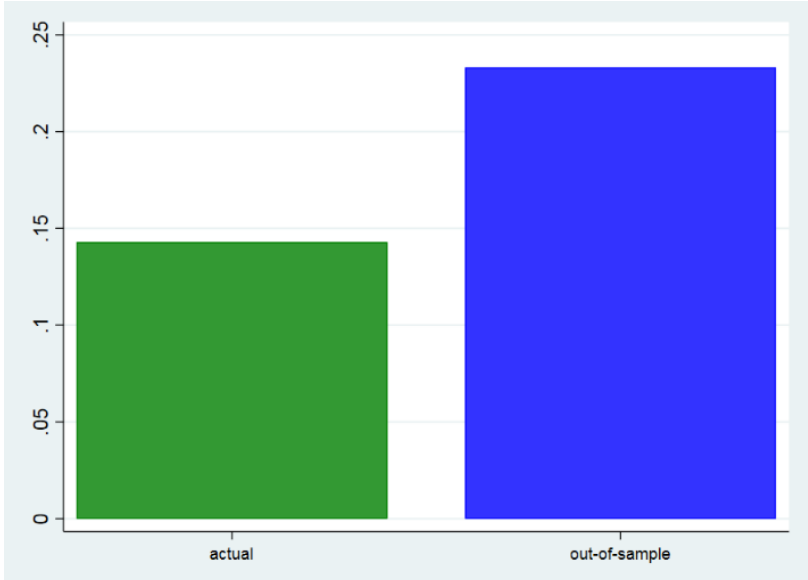


Table 1: Summary statistics

Panel A

\begin{tabular}{lccccc}
\hline & (A) & (B) & $(\mathrm{C})$ & (D) & (F) \\
\cline { 2 - 6 } & $\begin{array}{c}\text { Total crisis } \\
\text { episodes }\end{array}$ & $\begin{array}{c}\text { Episodes with pre- \& post- } \\
\text { crisis data } \\
\text { No. }\end{array}$ & $\begin{array}{c}\text { No. } \\
\text { col. B / col. A (\%) }\end{array}$ & $\begin{array}{c}\text { Episodes with peak } \\
\text { NPLs }>=7 \% \\
\text { col. D / col. B } \\
(\%)\end{array}$ \\
\hline All & 88 & 73 & 83.0 & 59 & 80.8 \\
Asian financial crisis, Asia & 8 & 8 & 100.0 & 8 & 100.0 \\
Asian financial crisis, non-Asia & 5 & 4 & 80.0 & 4 & 100.0 \\
Global financial crisis & 27 & 27 & 100.0 & 16 & 59.3 \\
Low-income countries & 13 & 9 & 69.2 & 7 & 77.8 \\
Transition, EU accession & 7 & 6 & 85.7 & 6 & 100.0 \\
Transition, non-EU accession & 10 & 2 & 20.0 & 2 & 100.0 \\
Nordic & 3 & 3 & 100.0 & 3 & 100.0 \\
Other, non-Nordic & 15 & 14 & 93.3 & 13 & 92.9
\end{tabular}

Panel B

\begin{tabular}{|c|c|c|c|c|c|c|}
\hline & \multicolumn{2}{|c|}{ Peak NPLs (mean) } & \multirow{2}{*}{$\begin{array}{c}\text { Time to } \\
\text { peak (mean, } \\
\text { year from } T \text { ) }\end{array}$} & \multirow{2}{*}{$\begin{array}{c}\text { Time to } \\
\text { resolve } \\
\text { (mean, year } \\
\text { from T) }\end{array}$} & \multicolumn{2}{|c|}{ No. resolved in 7 years } \\
\hline & $\begin{array}{c}\% \text { of total } \\
\text { loans }\end{array}$ & $\begin{array}{l}\text { relative to } \\
\text { NPLs at T }\end{array}$ & & & NPLs $<7 \%$ & $\begin{array}{c}\text { NPLs }<25 \% \\
\text { of peak }\end{array}$ \\
\hline $\begin{array}{l}\text { All (with peak } \\
\text { NPLs }>=7 \% \text { ) }\end{array}$ & 21.6 & 2.9 & 2.4 & 5.4 & 38 & 58 \\
\hline $\begin{array}{l}\text { Asian financial } \\
\text { crisis, Asia }\end{array}$ & 24.6 & 3.9 & 2.1 & 6.8 & 4 & 8 \\
\hline $\begin{array}{l}\text { Asian financial } \\
\text { crisis, non-Asia }\end{array}$ & 33.2 & 1.0 & 0.5 & 4.3 & 4 & 4 \\
\hline $\begin{array}{l}\text { Global financial } \\
\text { crisis }\end{array}$ & 15.9 & 3.6 & 3.7 & 6.2 & 6 & 15 \\
\hline $\begin{array}{l}\text { Low-income } \\
\text { countries }\end{array}$ & 28.7 & 2.4 & 2.9 & 6.0 & 3 & 7 \\
\hline $\begin{array}{l}\text { Transition, EU } \\
\text { accession }\end{array}$ & 26.7 & 1.6 & 1.8 & 6.0 & 5 & 6 \\
\hline $\begin{array}{l}\text { Transition, non-EU } \\
\text { accession }\end{array}$ & 22.7 & 2.5 & 4.0 & 5.5 & 1 & 2 \\
\hline Nordic & 9.8 & 1.7 & 0.7 & 3.0 & 3 & 3 \\
\hline Other, non-Nordic & 23.8 & 2.7 & 1.6 & 4.0 & 12 & 13 \\
\hline
\end{tabular}


Table 1: Summary statistics (cont')

$\underline{\text { Panel C }}$

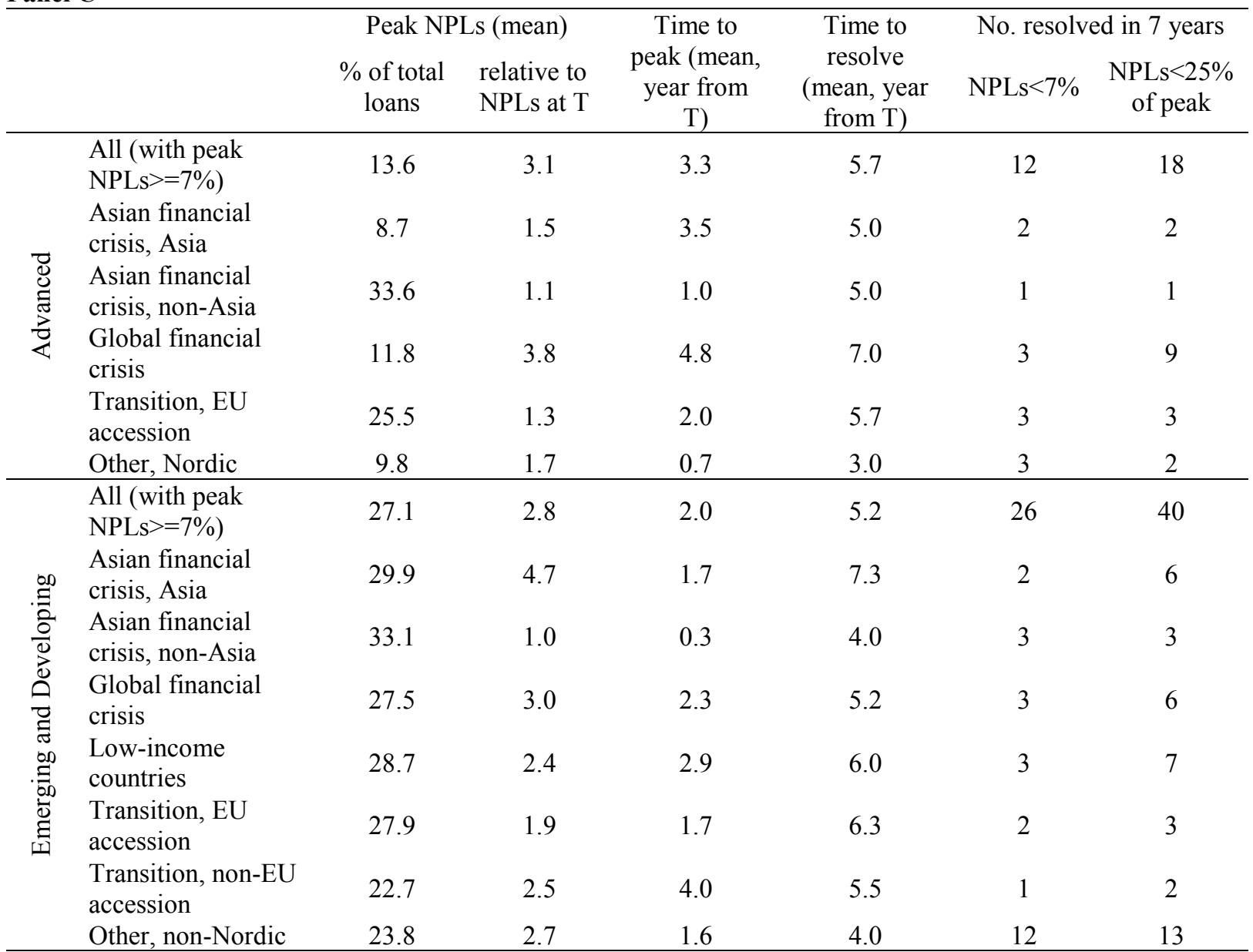

Note: Panel A shows the number of crises episodes in our sample period (1990-2017), with pre- and post-crisis NPL data, and with peak NPLs greater or equal to 7 percent of total loans. Panel B and C show summary statistics for the sample of crises with peak NPLs greater or equal to 7 percent of total loans. T is the starting year of the crisis as identified by Laeven and Valencia $(2013,2018)$. 


\section{Table 2: NPLs and output dynamics}

Panel A: Local projection conditional paths for real growth, by elevated and low NPLs

\begin{tabular}{lcccccc}
\hline & $(1)$ & $(2)$ & $(3)$ & $(4)$ & $(5)$ & $(6)$ \\
& Year 1 & Year 2 & Year 3 & Year 4 & Year 5 & Year 6 \\
\hline Crisis x Elevated NPLs & $-2.639^{*}$ & $-4.614^{* *}$ & $-6.273^{* *}$ & $-7.916^{* *}$ & $-8.638^{* *}$ & $-9.133^{*}$ \\
& $(1.550)$ & $(1.741)$ & $(2.361)$ & $(3.281)$ & $(3.993)$ & $(4.647)$ \\
Asian Financial Crisis dummy & 4.305 & 6.070 & $9.008^{* *}$ & $10.123^{*}$ & $11.997^{*}$ & $15.656^{* *}$ \\
& $(3.816)$ & $(3.957)$ & $(4.278)$ & $(5.381)$ & $(6.246)$ & $(7.175)$ \\
Other crises dummy & $6.394^{* *}$ & $6.954^{*}$ & $8.538^{*}$ & $14.866^{* * *}$ & $14.571^{* *}$ & $15.317^{* *}$ \\
& $(2.859)$ & $(3.529)$ & $(4.447)$ & $(4.535)$ & $(5.536)$ & $(6.273)$ \\
Low-income crises dummy & 3.826 & $8.902^{* *}$ & $13.539^{* * *}$ & $17.344^{* * *}$ & $18.555^{* * *}$ & $19.677^{* * *}$ \\
& $(2.649)$ & $(3.454)$ & $(4.207)$ & $(5.260)$ & $(6.172)$ & $(6.692)$ \\
Constant & $-4.166^{* *}$ & $-5.074 * * *$ & $-4.678^{* *}$ & $-6.033^{* *}$ & $-6.437^{*}$ & -4.949 \\
& $(1.610)$ & $(1.505)$ & $(1.939)$ & $(2.680)$ & $(3.379)$ & $(3.950)$ \\
Observations & 49 & 49 & 49 & 47 & 47 & 47 \\
R-squared & 0.360 & 0.494 & 0.519 & 0.548 & 0.538 & 0.553 \\
Macro control & Yes & Yes & Yes & Yes & Yes & Yes \\
\hline
\end{tabular}

Panel B: Local projection conditional paths for real growth, by NPL resolution

\begin{tabular}{lcccccc}
\hline & $(1)$ & $(2)$ & $(3)$ & $(4)$ & $(5)$ & $(6)$ \\
& Year 1 & Year 2 & Year 3 & Year 4 & Year 5 & Year 6 \\
\hline Crisis x Resolved NPLs & 2.023 & $7.986^{* * *}$ & $7.815^{* *}$ & $12.813^{* * *}$ & $16.028^{* * *}$ & $16.495^{* * *}$ \\
& $(1.980)$ & $(2.220)$ & $(3.043)$ & $(3.960)$ & $(4.925)$ & $(5.317)$ \\
Asian Financial Crisis dummy & 5.417 & $6.620^{* *}$ & $9.248^{* *}$ & $11.834^{* *}$ & $13.726^{* * *}$ & $14.693^{* * *}$ \\
& $(3.754)$ & $(2.800)$ & $(3.569)$ & $(4.631)$ & $(4.605)$ & $(4.576)$ \\
Other crises dummy & $6.327^{*}$ & 5.062 & $6.913^{*}$ & $12.766^{* * *}$ & 5.375 & $11.769^{*}$ \\
& $(3.174)$ & $(3.040)$ & $(3.767)$ & $(4.404)$ & $(5.047)$ & $(6.211)$ \\
Low-income crises dummy & 3.786 & $7.262^{* *}$ & $12.506^{* * *}$ & $16.181^{* * *}$ & $13.354^{* *}$ & 6.630 \\
& $(2.774)$ & $(2.782)$ & $(3.737)$ & $(4.325)$ & $(5.682)$ & $(6.868)$ \\
Constant & $-7.551^{* * *}$ & $-12.479^{* * *}$ & $-12.992^{* * *}$ & $-18.741^{* * *}$ & $-21.165^{* * *}$ & $-20.709^{* *}$ \\
& $(2.341)$ & $(2.457)$ & $(3.572)$ & $(5.448)$ & $(6.360)$ & $(7.926)$ \\
Observations & 38 & 38 & 38 & 36 & 34 & 34 \\
R-squared & 0.413 & 0.683 & 0.625 & 0.687 & 0.751 & 0.744 \\
Macro control & Yes & Yes & Yes & Yes & Yes & Yes \\
\hline
\end{tabular}

Note: This table reports the result of a local projection model estimating the average cumulated response of real GDP relative to the crisis year (year zero) across crises from a set of regressions at each horizon after the crisis year. The dependent variable is the log of real GDP (relative to year zero, multiplied by 100). Controls (not shown) include two lags of exchange rate, debt to GDP ratio, credit to the private sector (all measured in first difference), two lags of real GDP (in log first difference), and two lags of NPL to total loans ratio. The default group for crisis wave fixed effects is the GFC. Elevated NPLs is a dummy variable if peak NPLs are above 7 percent of total loans. Resolved NPLs is a dummy variable if NPLs are below 7 percent of total loans in year t. Standard errors in parentheses. $* * * * *$ and $*$ respectively indicate 1,5 and 10 percent significance levels. 
Table 3: Model selection results

Panel A: Probability of elevated NPLs

Dependent variable:

Elevated NPLs

dummy

(Peak NPLs>7\%)

GDP per capita

Corporate debt to

asset ratio

\begin{tabular}{lccc}
\hline No. of observations & 59 & 43 & 35 \\
Log likelihood & -29.19 & -15.55 & -6.98 \\
Adj. Pseudo R ${ }^{2}$ & 0.418 & 0.836 & 0.862 \\
\hline
\end{tabular}

Macro

(2)

(3)

$-0.268 * * * \quad-0.316 * * * \quad-0.498 * * *$

(0.041)

(0.016)

$(0.177)$

\section{Panel B: Peak NPLs}

Dependent variable:

Peak NPLs

(\% of total loans)

Bank return on

assets

$4.019 *$

Corporate

short-term debt

(2.190)

\begin{tabular}{lccc}
\hline No. of observations & 47 & 32 & 24 \\
R $^{2}$ & 0.194 & 0.142 & 0.209 \\
Adj. $\mathrm{R}^{2}$ & 0.138 & 0.113 & 0.134 \\
\hline
\end{tabular}


Table 3: Model selection results (cont')

\begin{tabular}{|c|c|c|c|c|c|c|c|}
\hline \multicolumn{2}{|l|}{ Panel C: Time to peak } & & & \multicolumn{4}{|c|}{ Panel D: Time to resolve } \\
\hline \multirow{3}{*}{$\begin{array}{l}\text { Dependent variable: } \\
\text { Time to peak }\end{array}$} & \multicolumn{3}{|c|}{ Specification } & \multirow{3}{*}{$\begin{array}{l}\text { Dependent variable: } \\
\text { Time to resolve }\end{array}$} & \multicolumn{3}{|c|}{ Specification } \\
\hline & (1) & (2) & (3) & & (1) & (2) & (3) \\
\hline & Macro & Bank & Corporate & & Macro & Bank & Corporate \\
\hline GDP per capita & & $\begin{array}{l}1.215^{* *} \\
(0.440)\end{array}$ & & $\begin{array}{l}\text { Government debt-to- } \\
\text { GDP ratio (gross) }\end{array}$ & & & $\begin{array}{l}1.077 * * * \\
(0.321)\end{array}$ \\
\hline GDP growth & $\begin{array}{l}-0.999 * * * \\
(0.251)\end{array}$ & & & $\begin{array}{l}\text { Change in domestic } \\
\text { credit to private sector }\end{array}$ & $\begin{array}{l}1.229 * * * \\
(0.262)\end{array}$ & $\begin{array}{l}0.748 * * \\
(0.327)\end{array}$ & $\begin{array}{l}1.338 * * * \\
(0.360)\end{array}$ \\
\hline $\begin{array}{l}\text { Change in } \\
\text { unemployment rate }\end{array}$ & & $\begin{array}{c}-0.450 * * \\
(0.206)\end{array}$ & & & & & \\
\hline $\begin{array}{l}\text { Exchange rate regime } \\
\text { change }\end{array}$ & & & $\begin{array}{l}-1.170 * * \\
(0.493)\end{array}$ & & & & \\
\hline $\begin{array}{l}\text { Exchange rate depreciation } \\
\text { against USD }\end{array}$ & & $\begin{array}{c}-1.123^{* * *} \\
(0.373)\end{array}$ & $\begin{array}{c}-0.840 * * * \\
(0.292)\end{array}$ & & & & \\
\hline $\begin{array}{l}\text { Government debt-to-GDP } \\
\text { ratio (gross) }\end{array}$ & & & $\begin{array}{l}0.949 * * * \\
(0.249)\end{array}$ & & & & \\
\hline $\begin{array}{l}\text { Change in domestic credit } \\
\text { to private sector }\end{array}$ & $\begin{array}{c}0.743 * * \\
(0.366)\end{array}$ & & & & & & \\
\hline $\begin{array}{l}\text { Corporate short-term debt } \\
\text { (as } \% \text { of total debt) }\end{array}$ & & & $\begin{array}{l}-0.551 * \\
(0.317)\end{array}$ & & & & \\
\hline No. of observations & 47 & 32 & 24 & No. of observations & 43 & 29 & 23 \\
\hline Log likelihood & -93.22 & -52.78 & -35.75 & Log likelihood & -78.76 & -44.41 & -34.75 \\
\hline Adj. Pseudo $\mathrm{R}^{2}$ & 0.032 & 0.138 & 0.228 & Adj. Pseudo $\mathrm{R}^{2}$ & 0.064 & 0.035 & 0.120 \\
\hline
\end{tabular}


Table 3: Model selection results (cont')

\begin{tabular}{|c|c|c|c|}
\hline $\begin{array}{l}\text { Dependent variable: } \\
\text { NPL resolution dummy }\end{array}$ & $\begin{array}{c}(1) \\
\text { Macro }\end{array}$ & $\begin{array}{c}\text { ecification } \\
\text { (2) } \\
\text { Bank } \\
\end{array}$ & $\begin{array}{c}(3) \\
\text { Corporate }\end{array}$ \\
\hline GDP growth & $\begin{array}{c}0.119 * * * \\
(0.040)\end{array}$ & & \\
\hline $\begin{array}{l}\text { Change in } \\
\text { unemployment rate }\end{array}$ & $\begin{array}{l}0.118 * * * \\
(0.044)\end{array}$ & $\begin{array}{l}0.112 * * \\
(0.054)\end{array}$ & \\
\hline $\begin{array}{l}\text { Exchange rate } \\
\text { depreciation against USD }\end{array}$ & & $\begin{array}{l}0.322 * * * \\
(0.108)\end{array}$ & \\
\hline $\begin{array}{l}\text { Government debt-to-GDP } \\
\text { ratio (gross) }\end{array}$ & & & $\begin{array}{c}-0.150 * * \\
(0.064)\end{array}$ \\
\hline $\begin{array}{l}\text { Change in government } \\
\text { debt-to-GDP ratio (gross) }\end{array}$ & $\begin{array}{c}-0.160 * * * \\
(0.049)\end{array}$ & & \\
\hline $\begin{array}{l}\text { Change in domestic credit } \\
\text { to private sector }\end{array}$ & $\begin{array}{c}-0.289 * * * \\
(0.044)\end{array}$ & & \\
\hline $\begin{array}{l}\text { Bank noninterest income } \\
\text { to total income ratio }\end{array}$ & & $\begin{array}{l}0.151 * * * \\
(0.056)\end{array}$ & \\
\hline $\begin{array}{l}\text { Corporate current asset to } \\
\text { liability ratio }\end{array}$ & & & $\begin{array}{c}-0.121 * * * \\
(0.039)\end{array}$ \\
\hline No. of observations & 44 & 30 & 24 \\
\hline Log likelihood & -18.37 & -11.14 & -8.20 \\
\hline Adj. Pseudo R ${ }^{2}$ & 0.200 & 0.284 & 0.157 \\
\hline
\end{tabular}

Notes: Robust standard errors are in parentheses. $* * *, * *$ and $*$ respectively indicate 1,5 and 10 percent significance levels. Panel A is based on observations from the whole sample of banking crises for which sufficient data on NPL dynamics and candidate predictors are available. Panels B-E are based on the subset of crises with elevated NPLs (i.e. peak NPL ratio over 7 percent). Predictors are selected using the post-r-lasso estimator (Belloni et al., 2012; Belloni and Chernozhukov, 2013). For the second step estimates, Panels A, E report results from logistic regressions and C, D report results from Tobit regressions. The coefficients reported in these panels correspond to marginal effects. Panel B reports OLS results. Change refers to cumulative change over the 5 years prior to the banking crisis. All other variables represent average values over the same period. Coefficients for intercepts and statistically insignificant predictors are not reported. Adjusted Pseudo $\mathrm{R}^{2}$ values are calculated according to McFadden (1974). See Appendix Table A3, C1, and C2 for variable definitions, data sources and further details on specifications. 
Table 4: Summary of predictors

Panel A: Dependent variable is high NPL probability

\begin{tabular}{lll}
\hline Predictor category & $\begin{array}{l}\text { Predictors for the baseline definition } \\
(\mathrm{NPL}>7 \%)\end{array}$ & $\begin{array}{l}\text { Predictors for an alternative definition } \\
(\mathrm{NPL}>5 \%)\end{array}$ \\
\hline Macroeconomic & GDP per capita & $\begin{array}{l}\text { GDP per capita } \\
\text { Change in domestic credit to private sector }\end{array}$ \\
\hline Corporate & Corporate debt to asset ratio & Corporate debt to asset ratio \\
\hline Predictor category & $\begin{array}{l}\text { Predictors for the baseline definition (\% of } \\
\text { total loans) }\end{array}$ & $\begin{array}{l}\text { Predictors for an alternative definition } \\
\text { (relative to NPL ratio at crisis date) }\end{array}$ \\
\hline Macroeconomic & & Exchange rate depreciation against USD \\
\hline Bank & Bank return on assets & \\
\hline Corporate & Corporate short-term debt (as \% of total debt) & \\
\hline
\end{tabular}

Panel C: Dependent variable is time to peak

\begin{tabular}{lll}
\hline Predictor category & $\begin{array}{l}\text { Predictors for the baseline definition (relative } \\
\text { to crisis year) }\end{array}$ & $\begin{array}{l}\text { Predictors for an alternative definition } \\
\text { (relative to first year when NPL > 7\%) }\end{array}$ \\
\hline & $\begin{array}{l}\text { GDP per capita } \\
\text { GDP growth } \\
\text { Change in unemployment rate } \\
\text { Exchange rate regime change } \\
\text { Exchange rate depreciation against USD } \\
\text { Government debt-to-GDP ratio (gross) } \\
\text { Change in domestic credit to private sector }\end{array}$ \\
\hline Corporate & Corporate short-term debt (as \% of total debt) \\
\hline
\end{tabular}


Table 4: Summary of predictors (cont')

Panel D: Dependent variable is time to resolve

\begin{tabular}{lll}
\hline \multicolumn{2}{c}{ Panel D: Dependent variable is time to resolve } \\
\hline Predictor category & $\begin{array}{l}\text { Predictors for the baseline definition (relative } \\
\text { to crisis year) }\end{array}$ & $\begin{array}{l}\text { Predictors for an alternative definition } \\
\text { (relative to first year when NPL }>7 \%)\end{array}$ \\
\hline Macroeconomic & $\begin{array}{l}\text { Government debt-to-GDP ratio (gross) } \\
\text { Change in domestic credit to private sector }\end{array}$ & $\begin{array}{l}\text { Change in government debt-to-GDP } \\
\text { ratio (gross) }\end{array}$ \\
\hline Bank & & $\begin{array}{l}\text { Bank operating expenses as a share of net- } \\
\text { interest }\end{array}$ \\
\hline
\end{tabular}

Panel E: Dependent variable is NPL resolution probability

\begin{tabular}{lll}
\hline \multirow{2}{*}{ Predictor category } & $\begin{array}{l}\text { Predictors for the baseline definition (NPLs }< \\
7 \% \text { of total loans } 7 \text { years after a crisis) }\end{array}$ & $\begin{array}{l}\text { Predictors for an alternative definition } \\
\text { (NPLs }<25 \% \text { of peak) }\end{array}$ \\
\hline \multirow{3}{*}{ Macroeconomic } & $\begin{array}{l}\text { GDP growth } \\
\text { Change in unemployment rate } \\
\text { Exchange rate depreciation against USD } \\
\text { Government debt-to-GDP ratio (gross) } \\
\text { Change in government debt-to-GDP ratio } \\
\text { (gross) } \\
\text { Change in domestic credit to private sector }\end{array}$ & $\begin{array}{l}\text { Exchange rate peg } \\
\text { Exchange rate depreciation against USD } \\
\text { Government debt-to-GDP ratio (gross) } \\
\text { Change in government debt-to-GDP } \\
\text { ratio (gross) } \\
\text { Change in domestic credit to private } \\
\text { sector }\end{array}$ \\
\hline Bank & $\begin{array}{l}\text { Bank noninterest income to total income } \\
\text { ratio }\end{array}$ & Bank noninterest income to total income \\
\hline Corporate & Corporate current asset to liability ratio & Corporate debt to asset ratio \\
\hline
\end{tabular}

Note: This table summarizes predictors under the baseline and alternative definitions of NPL dynamics. Identical or conceptually similar predictors under the baseline and alternative definitions are in bold. 